\title{
PERFORMING AND PRESERVING MEMORIES: \\ VERNACULAR PHOTOGRAPHS IN THE SOUTH VIETNAMESE DIASPORA
}

by

\author{
Julia Trúc Hạ Huỳnh \\ Bachelor of Arts, University of Toronto, 2015 \\ Diploma of Fine Arts, Sheridan College, 2015 \\ A thesis \\ presented to Ryerson University \\ in partial fulfillment of the \\ requirements for the degree of \\ Master of Arts \\ in the program of \\ Film and Photography Preservation and Collections Management
}

Toronto, Ontario, Canada, 2019

(C) Julia Trúc Hạ Huỳnh, 2019 


\section{Author's Declaration}

\section{AUTHOR'S DECLARATION FOR ELECTRONIC SUBMISSION OF A THESIS}

I hereby declare that I am the sole author of this thesis. This is a true copy of the thesis, including any required final revisions, as accepted by my examiners.

I authorize Ryerson University to lend this thesis to other institutions or individuals for the purpose of scholarly research.

I further authorize Ryerson University to reproduce this thesis by photocopying or by other means, in total or in part at the request of other institutions or individuals for the purpose of scholarly research.

I understand that my thesis may be made electronically available to the public. 


\title{
Abstract
}

\section{PERFORMING AND PRESERVING MEMORIES: \\ VERNACULAR PHOTOGRAPHS IN THE SOUTH VIETNAMESE DIASPORA}

\author{
Julia Trúc Hạ Huỳnh \\ Master of Arts
}

Film and Photography Preservation and Collections Management, Ryerson University

2019

This thesis explores how photographs from 1980-1995 of the South Vietnamese diasporic community in Orange County, California communicate selective ideas about exilic identity and memory following the militarized migration of this refugee community fleeing war. Focusing on two case studies drawn from photographs included in the Paul Tran Files and the Project Ngọc Records, the thesis investigates the (in)visible desires of the community and how such desires are (re)produced and mediated through images. Vernacular photographs of commemorative events produced by the community are crucial to our understanding of the visual tropes used to anchor the Vietnamese diasporic identity. Additionally, the photographs themselves function as a means of contesting nation building and for intergenerational transmission of memory. Just as importantly, an examination of the photographs' multi-temporal and serial qualities reveals how youth are culturally disciplined through the gendered labour of memory keeping. 


\section{Dedication}

This thesis is dedicated to other children of Vietnamese refugees who are navigating the memories not of their own while trying to grapple with their own diasporic identities.

I would also like to dedicate this to other students of colour who are the first in their families to pursue a graduate degree who may be researching, writing and confronting their community's histories for the first time as well. This is not an easy task, but your truth, your history and your unique insights are important. Do not let anyone tell you otherwise. 


\section{Acknowledgments}

Thank you to my external first reader, Dr. Thy Phu, Associate Professor in the Department of English and Writing Studies at Western University, for your mentorship and warm generosity in taking the time to review my thesis throughout its multiple stages. Your guidance and knowledge of photography and the Vietnamese diaspora was invaluable towards the completion of this thesis.

Thank you to my external second reader Dr. Dorothy Fujita-Rony, Associate Professor of Asian American Studies at the University of California Irvine, for your insight, enthusiasm and encouraging feedback.

Thank you to my second reader, Alison Skyrme, Special Collections Librarian at Ryerson University Library and Archives for offering your diligent editing and input.

Thank you to Dr. Thuy Võ Đăng, Curator and Research Librarian of the Southeast Asian Archive, for kindly offering meaningful research support, mentorship and your positivity as well as sharing resources from your personal library.

Thank you to several of my colleagues at the Southeast Asian Archive and Special Collections at $\mathrm{UCI}$ for your support and words of encouragement.

Thank you to the 4+1 MA cohort in Asian American studies for welcoming me with open arms and becoming a supportive community throughout my residency and for being wonderful and inspiring lights throughout this process.

Thank you to my peers in the F+PPCM cohort for cheering me on.

To my family and friends, I would like to extend my sincere gratitude for believing in me and reminding me again who this thesis is for and its importance. Thank you to my parents Quyên Từ and Tấn Võ Huỳnh for teaching me about our Vietnamese culture and heritage in the best ways they could. Thank you also to my mom for reviewing my Vietnamese interpretations and translations throughout this thesis.

Lastly, thank you to those who paved the way before me.

Cảm ơn nhiều. 


\section{Table of Contents}

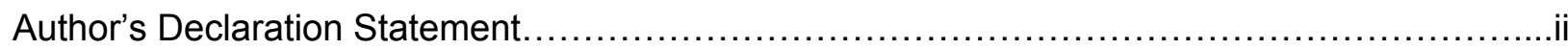

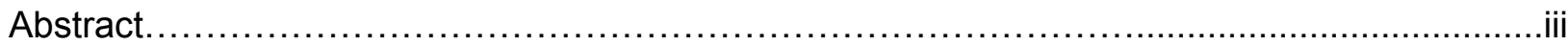

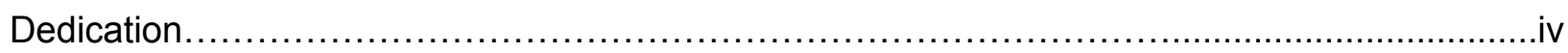

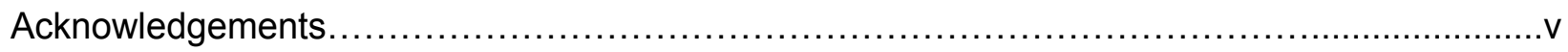

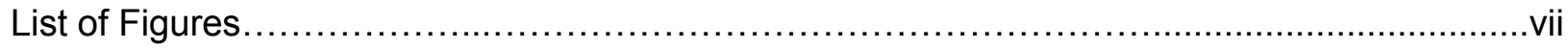

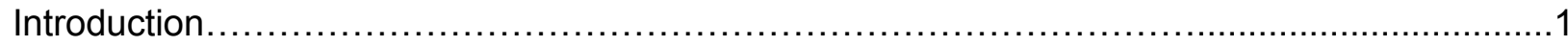

The Southeast Asian Archive in Orange County, California.......................................5

Literature Review. $\ldots \ldots \ldots \ldots \ldots \ldots \ldots \ldots \ldots \ldots \ldots \ldots \ldots \ldots \ldots \ldots \ldots \ldots \ldots \ldots \ldots \ldots \ldots \ldots \ldots \ldots \ldots \ldots \ldots . .8$

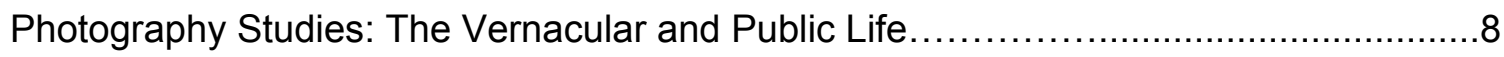

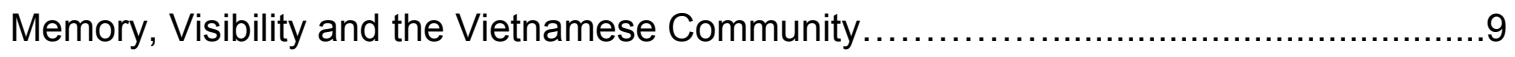

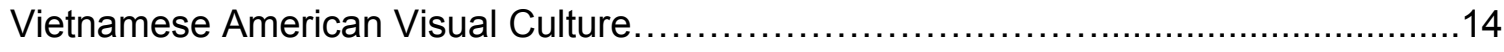

The Teachings of the Past in the Paul Tran Files.................................................16

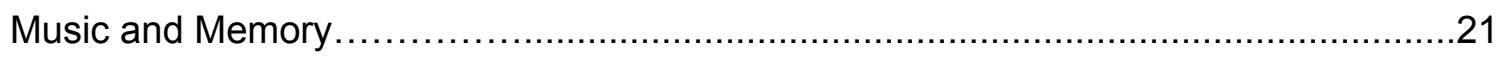

Intergenerational Spectatorship and Participation.......................................

Youth Performing and Carrying the Past From the Project Ngọc Records.........................32

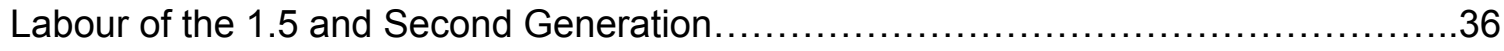

Vietnamese American Women: Performing the Virtues and Values of the Diaspora......43

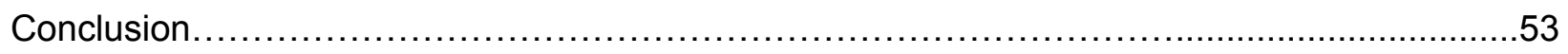

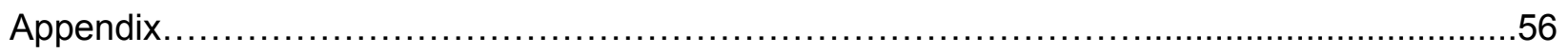

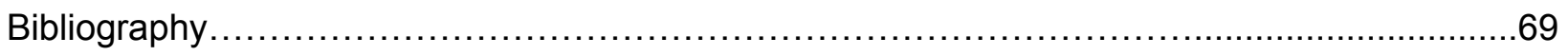




\section{List of Figures}

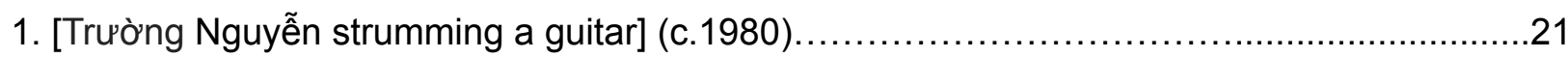

1a. Verso of [Trường Nguyễn strumming a guitar] (c.1980) ........................56

2. [Cao Tôn Kháng and Thúy Hiền performance] (c. 1980) ..................................22

2a. Verso of [Cao Tôn Kháng and Thúy Hiền performance] (c.1980) $\ldots \ldots \ldots \ldots \ldots \ldots \ldots \ldots . \ldots \ldots$

3. [UCLA choir performance of "Ly Rượu Mùng"] (c.1980) ....................................25

3a. Verso of [UCLA choir performance of "Ly Rượu Mừng"] (c. 1980) .....................58

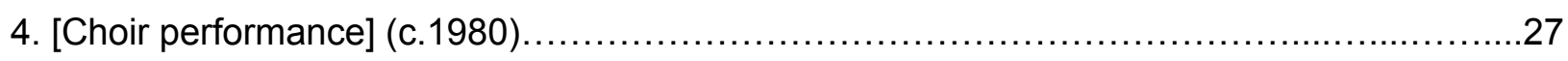

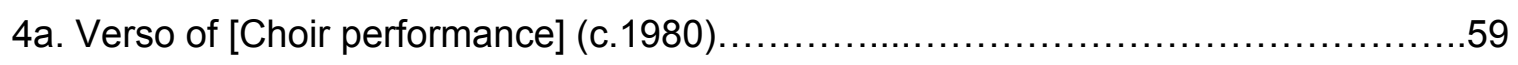

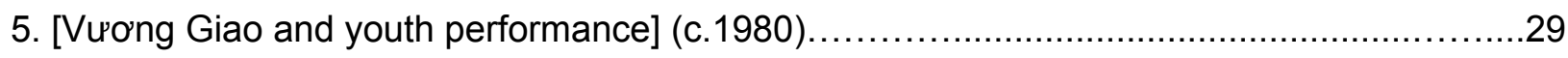

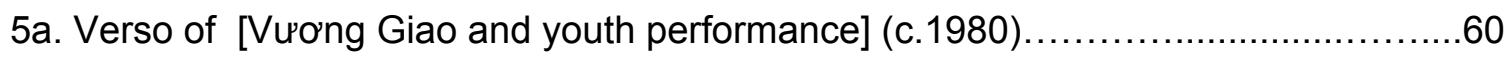

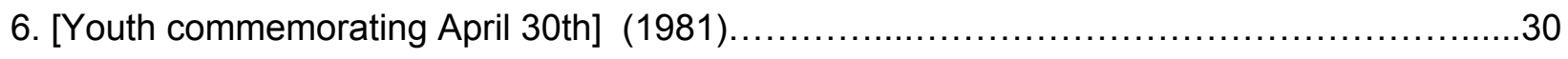

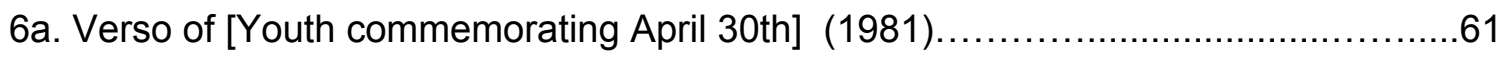

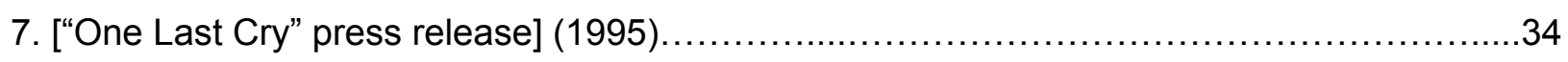

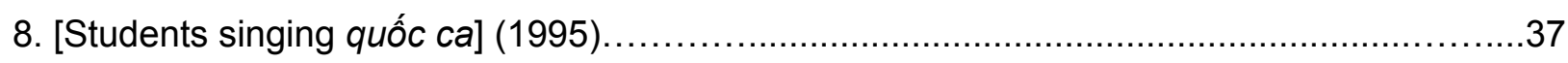

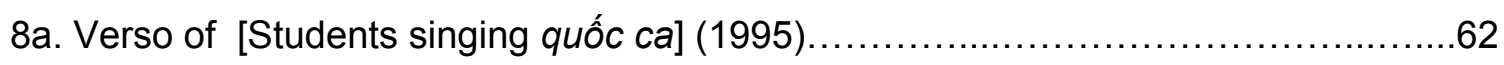

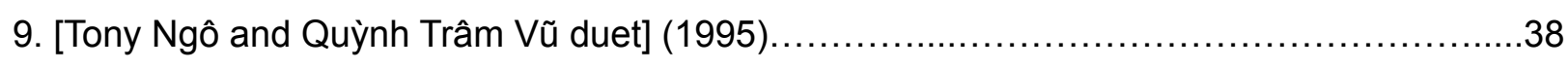

9a. Verso of [Tony Ngô and Quỳnh Trâm Vũ duet] (1995)............................63

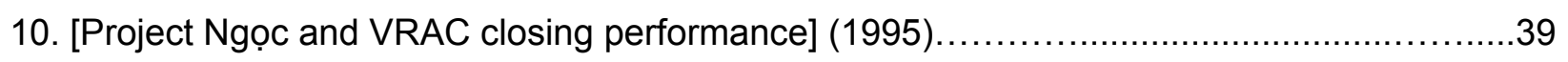

10a. Verso of [Project Ngọc and VRAC closing performance] (1995).................64

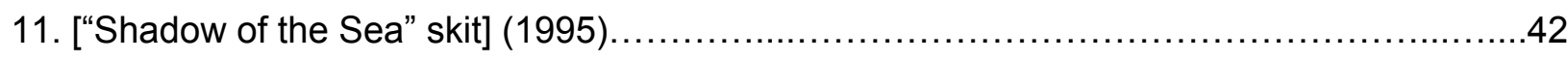

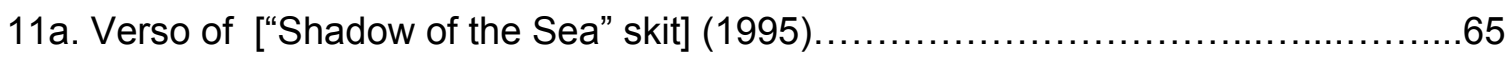

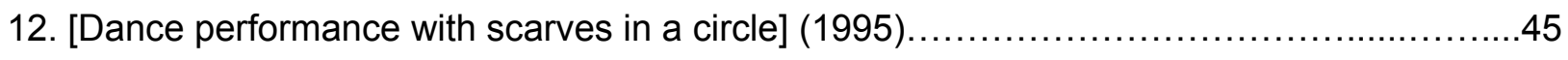

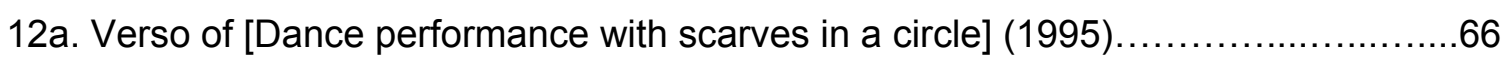


13. [Dance performance with scarves] (1995).....

13a. Verso of [Dance performance with scarves] (1995) ..........................67

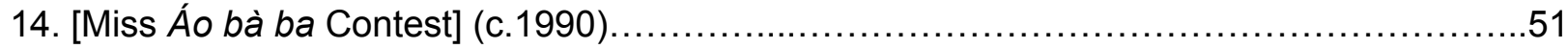

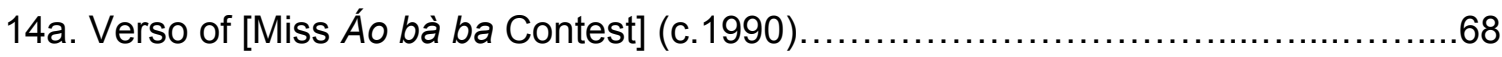




\section{Introduction}

As a daughter of South Vietnamese refugees and a second generation Vietnamese Canadian, I have been grappling with understanding what a Vietnamese identity looks like. This identity is complicated and multi-faceted. However, I feel that only one type of Vietnameseness is dominant in my community; to be authentically Vietnamese in the diaspora, is to be South Vietnamese. Growing up, I was told to remember my roots always, a task that entails remembering quê hưong, the homeland. I am confronted with the obvious issue that the homeland I am urged to honour is one to which I have no direct connection. And yet, when I see the heritage flag of my community or watch moving performances commemorating April 30th, I can feel the pain and sorrow of a lost nation and a longing for its return. These emotions are confusing and complex as I catch myself imagining and romanticizing an old Việt Nam—one that existed before the end of the Việt Nam War. While I did not directly experience these events, where did I learn these ideas and how have I taken on memories that are not my own?

Although my family and I lived in Peterborough, Ontario, Canada — a predominantly white town -- we were still able to connect with others across the Vietnamese diaspora. ${ }^{1} \mathrm{We}$ were able to do so through our trips to Toronto where my parents collected "Paris By Night" VHS tape performances and gathered copies of the Vietnamese daily newspapers. The papers often highlighted local and global Vietnamase diasporic news, publishing photographs in both colour and black and white of events such as fundraisers, pageants, and gatherings to remember the Fall of Saigon on April 30th in 1975. Unknown to me at the time, my daily encounters to these diaspora produced media in our home were informing me of a South Vietnamese diasporic identity.

\footnotetext{
${ }^{1}$ In 2016, Peterborough, Ontario had a population of 82,000 in which $0.0018 \%$ identify as Vietnamese. "2016 Census," Statistics Canada 2017 Profile, Statistics Canada Catalogue no. 98-316-X2016001 Ottawa, accessed June 23, 2019, http://www12.statcan.gc.ca/census-recensement/2016/dp-pd/prof/index.cfm?Lang=E.
} 
In this thesis, I attend to vernacular photographs of Vietnamese remembrance gatherings from the early ' 80 s and mid ' 90 s in Orange County, California, where I am completing my residency. During this period, there is a political urgency of the exilic community to present themselves in the context of a lost nation. ${ }^{2}$ What do vernacular photographs disclose about the (in)visible desires of the community and how are these desires (re)produced ${ }^{3}$ The very quality of vernacular images, with their seemingly endless quantity along with their repetition and recycled uses of visual signifiers, allows me to interrogate how these images influenced the community and its selective, collective memory. Moreover, the repetition of photographs documenting these acts of remembrance anchors community memory as they navigate their exilic identity as South Vietnamese over space, time and across generations.

The photographs also function as a means for the intergenerational transmission of memory, a process that critic Marianne Hirsch examines through the lens of "postmemory." ${ }^{4}$ The photographs of such events are particularly important in conjuring these embodied longings of quê hương. As younger generations view these photographs, their parents' desires and memories of quê hương that they inherited, can continuously be brought forward to remember. Furthermore, these vernacular photographs culturally discipline the second generation. The repetition of visual signifiers reveal the gendered expectations and labour of memory keeping, which are imposed onto the younger generation and specifically, upon young Vietnamese American women.

\footnotetext{
${ }^{2}$ Long T. Bui, Returns of War: South Vietnam and the Price of Refugee Memory (New York University Press, 2018), 1.

${ }^{3}$ I contend that the desires of the South Vietnamese community to remember their homeland are hypervisible in their visual displays such as the use of the heritage flag or April 30th gatherings. These desires however, are invisible to the general public and become visible when we attend to vernacular photographs created by the community. When those in the South Vietnamese diaspora view these photographs of such gatherings, the images themselves produce and reproduce (hence, (re)produce) the visibilities of the community's desires and the pedagogical functions of these images to teach specific values and memories for future generations.

${ }^{4}$ Marianne Hirsch, The Generation of Postmemory: Writing and Visual Culture After the Holocaust (New York: Columbia University Press, 2012), 4.
} 
The very existence of these images produced in this diasporic community is extremely profound. Because this refugee community fled war, they lost their homes, belongings and their homeland of South Việt Nam to the communist regime. To be South Vietnamese is to have an exilic identity where a return to South Việt Nam becomes impossible. Hence, these photographs of ritualized performances of remembrance, empower the community to create a sense of stability where their homeland exists.

For the diasporic Vietnamese community that emerged out of war and trauma, commemorative events for gathering, remembrance and sharing in collective loss is one space where memory can be transmitted between the first, 1.5 and second generations. For the purpose of this thesis, first generation refers to adult Vietnamese that have a direct connection to the homeland and were a part of the first and second waves of the refugee exodus. The first wave of nearly 125,000 Vietnamese refugees that arrived in 1975 in the U.S. were educated, upper middle class and high ranking government or military officials. The second wave was generally comprised of working class from rural areas who arrived in the late 1970s, known to the greater public as the "boat people" for their method of escape. The 1.5 generation refers to children that also left Việt Nam during these waves however, they were too young to have been directly fighting in the war. In contrast, the second generation are those born in America and have no direct connection to Việt Nam or the war.

The media covered the Việt Nam War and the subsequent exodus of Vietnamese in the aftermath of this war so extensively that such events are often understood as "the most chronicled, documented, reported, filmed, taped and narrated war in US history." Việt Nam was thus hypervisible. This coverage tended to depict Vietnamese people within violent spectacles,

\footnotetext{
${ }^{5}$ Yến Lê Espiritu, Body Counts: The Vietnam war and Militarized Refuge(es) (University of California Press, 2014), 18.
} 
as sexualized bodies and pitied victims. ${ }^{6}$ Despite this hypervisibility, as Yến Lê Espiritu contends in Body Counts: The Vietnam War and Militarized Refuge(es), the Vietnamese become rendered as invisible through a historical amnesia and organized forgetting as products of U.S. militarism and imperialism. ${ }^{7}$

In addition, Vietnamese American scholars like Nhi T. Lieu and many others argue that the development of the Vietnamese American community within the Cold War and conservative discourse of anti-communism influenced the community's politics and their self-alignment as politically conservative. ${ }^{8}$ Therefore, for the Vietnamese in the U.S. to become "materially and discursively recognized" and to create their own historical narrative, they must engage in community-building and place-making as a means of navigating the past. ${ }^{9}$

Lieu likewise observes that, "the legacy of the image of the Vietnamese as refugee...not only shaped the ways in which Vietnamese Americans are represented...but also influenced their own identity formation." ${ }^{10}$ Thus, vernacular photographs of the Vietnamese diaspora produced in the diaspora have the ability to counteract the violent, visual narrative produced by

\footnotetext{
${ }^{6}$ Thy Phu, "Diasporic Vietnamese Family Photographs, Orphan Images, and the Art of Recollection," Trans Asia Photography Review 5, no.1 (Fall 2014): http://hdl.handle.net/2027/spo.7977573.0005.102. Note: Both Vietnamese American and Vietnamese Canadian scholars call to look at the everyday photographs to counteract these violent narratives. See also Jacinda Tran's "From Deadbeat Dad to Great Benefactors: Picturing Rescue by (Re)Scripting U.S. Masculinity through the 1988 Amerasian Homecoming Act" paper presented at the Society for Cinema and Media Studies Conference, Toronto, ON, March 18, 2018.

7 Other Southeast Asian communities have also been impacted by the legacies of U.S. imperialism and militarism. Media and cultural studies professor, Sarita Echavez See in The Filipino Primitive explores the crisis of visibility and over representations of "primitive" Filipinos in museums. Such visibilities in these institutions is racist and See argues that it is through such hypervisibility in the museum that the (in)visibility of the violence their community was subjected to from U.S. militarism and imperialism -becomes apparent.

${ }^{8}$ Nhi T. Lieu, "Private Desires on Public Display: Vietnamese American Identities in Multi-Mediated Leisure and Niche Entertainment" (PhD diss., University of Michigan, 2004), 24.

Other scholars such as Thuy Võ Đăng, Long T. Bui, Yến Lê Espiritu have explored the Vietnamese American community's employment of the anti-communist rhetoric.

${ }^{9}$ Karin Aguilar-San Juan, Little Saigons (Minneapolis: University of Minnesota Press, 2009), 63.

${ }^{10}$ Lieu, "Private Desires on Public Display," 24.
} 
the media. ${ }^{11}$ Such images hold the potential to illuminate how the community navigates the past in the aftermaths of war. Additionally, the repetition of visual signifiers used to anchor the community, illustrates the gendered labour of memory making and keeping. Therefore, the photographs also preserve such desires, values and teachings of the South Vietnamese diaspora for future generations as they turn to these images to understand their own diasporic identities.

\section{The Southeast Asian Archive in Orange County}

I encountered my primary sources while completing my residency at the Southeast Asian Archive (SEAA) at the University of California Irvine. Established in 1987 when librarian Anne Frank began collecting materials related to the Indochinese refugee movement, the SEAA developed to become the largest "collection of books, photographs, artwork and ephemera documenting peoples from Viet Nam, Cambodia, and Laos outside of their homelands." ${ }^{12}$ In doing so, the archive stands out from other state archives as it focuses solely on the experiences of refugee and diasporic communities.

The SEAA is situated in Southern California in Orange County about 13 miles from Little Saigon, (Westminster, California) the largest enclave of Vietnamese Americans. Today, California boasts the largest population of Vietnamese outside of Việt Nam, nearly 1.3 million Vietnamese immigrants, of which over 350,000 reside in Southern California. ${ }^{13}$ According to

\footnotetext{
${ }^{11}$ Four iconic images of the Viet Nam war persist in the public's knowledge of the war: the infamous photograph of Phan Thi Kim Phu known as the Napalm Girl, the self-immolating Buddhist monk, the death of a student at a Kent State University protest and lastly, the photograph capturing the moment a South Vietnamese general shot a North Vietnamese soldier.

12 "Southeast Asian American Studies: Studying the Vietnamese, Cambodian, and Laotian Diaspora," University of California Irvine Libraries, accessed March 20, 2019, https://guides.lib.uci.edu/southeastasianamerican.

${ }^{13}$ Josie Huang, "Infographic: 40 percent of nation's Vietnamese immigrants call California home," Multi-American, accessed May 10, 2019, https://www.scpr.org/blogs/multiamerican/2014/08/25/17200/california-vietnamese-immigrant-orange-cou nty/.
} 
Lieu, as Vietnamese Americans desired to form a collective identity, their struggle to do so is found in the history of the development of Little Saigon, a simulacra of Sài Gòn the former capital of Việt Nam. ${ }^{14}$

As case studies, I draw on a selection of photographs from two collections from SEAA: the Paul Tran Files and the Project Ngọc Records. These particular collections provide an important lens on diasporic identity formation between the first, 1.5 and second generation. Because the photographs in my case studies were created in Southern California, they reflect this particular region of the Vietnamese American diaspora. In limiting my scope to a collection that focuses on this specific region, I am careful to avoid creating a monolithic image of the Vietnamese diaspora. ${ }^{15}$ Instead, I am concerned with analyzing and further understanding how the South Vietnamese diaspora in Orange County represent themselves within the context of their lost homeland.

Orange County is home to the only Little Saigon to be officially recognized in America and it is described as "the center of exile politics" and the center of "political, social, and cultural life for Vietnamese in the diaspora." ${ }^{16}$ Likewise, diasporic Vietnamese entertainment industries thrive in Little Saigon, producing music, videos, radio stations as well as dozens of daily newspapers and magazines. ${ }^{17}$

My research, then, pays close attention to vernacular photographs produced and circulated in this diasporic community. Despite their banal features, vernacular images have pedagogical functions. Vernacular images are an important resource because their quotidian

\footnotetext{
${ }^{14}$ Lieu, "Private Desires on Public Display," 62.

${ }^{15}$ Of course, not everyone identifies as South Vietnamese and the Vitenamese people are displaced all over the world. Hence, their respective collective identity may or may not share similarities in maintaining an anti-communist rhetoric and their urgency to create a visual and collective identity may be different compared to the militarized refugees who have resettled in Southern California and have created a global center via Little Saigon for the diaspora.

Lieu, "Private Desires on Public Display," 62.

${ }^{16}$ Ibid, 58-59.

${ }^{17}$ Ibid, 59.
} 
quality paradoxically provides clues as to how the community projects its self-image. That said, the term vernacular when applied to photography has been controversial because of its development as a genre of photography that was intended to serve social functions and not necessarily artistic ones-leading to its critical neglect. ${ }^{18}$ However, as Geoffrey Batchen observes, the genre of vernacular photography represents "the visual culture of everyday life" and being conformist in character, they reproduce "established social and aesthetic conventions in an effort to fulfill certain functions for the maker and/for viewer." ${ }^{19}$ Therefore, vernacular photographs provide insights on the visual convention employed by the South Vietnamese community in Orange County to create a visible collective identity.

In addition, I turn to this genre of photography in my thesis because of their characteristically repetitive quality, manifest in a serial composition of images. This seriality serves as an entry point to understand how the anti-communist rhetoric of the South Vietnamese American community is anchored and recycled through the employment of visual tropes, most notably the heritage flag and traditional clothing, among others, as evident through the existence of such photographs. Moreover, the multi-temporality of vernacular photographs, a point that I explain in greater detail below, provide a means for unfolding the ways that intergenerational memory is transmitted. Lastly, I contend that because the vernacular establishes certain social conventions, they in turn culturally discipline the younger generation as viewers of the photographs.

\footnotetext{
${ }^{18}$ Geoffrey Batchen, "Vernacular Photography," Oxford Art Online, January 22, 2014, 1, https://doi.org/10.1093/gao/9781884446054.article.T2254188.

19 lbid.
} 


\section{Literature Review}

\section{Photography Studies: The Vernacular and Public Life}

To understand the meanings of photography, we need to consider more than just the subject of the photographs. In "Objects of Affect: Photography Beyond the Image," visual anthropologist Elizabeth Edwards argues that photographs must be "understood through an affective, embodied engagement. ${ }^{20}$ In discussing the material practices of photography, Edwards considers two performances of photographs: the remediation of the image from one purpose to another and the placing or framing of the meaning of a photographic object. Edwards notes that photographs play an integral role in the process of community coherence as they can "become embodied with social relations as active constituents of social networks." ${ }^{21}$ This is critically important as I observe how photographs themselves of commemorative events create a network connecting generations across time and space.

Like Edwards, Black diaspora studies scholar, Tina M. Campt in Image Matters: Archive, Photography, and the African Diaspora in Europe, addresses how photography is a performative act which complicates cultural and social relations. ${ }^{22}$ Campt argues that family photography enables the viewer to understand how diasporic formation is constituted through inclusion, exclusion and belonging and unbelonging as structuring the "nation, the family and diaspora." ${ }^{23}$ Furthermore, Campt calls for a method of reading through repetitive and similarly posed studio portraits by looking at the studium, or contextual (as opposed to affective) components of a photograph in order to interpret seriality. ${ }^{24}$ For Campt, to view the archive of

\footnotetext{
${ }^{20}$ Elizabeth Edwards, "Objects of Affect: Photography Beyond the Image," Annual Review of Anthropology 41, no. 41 (October 21, 2012): 221.

${ }^{21} \mathrm{Ibid}, 230$.

22 Tina M. Campt, Image Matters: Archive, Photography, and the African Diaspora in Europe (Duke University Press, 2012), 48.

${ }^{23}$ Campt, Image Matters, 55.

${ }^{24}$ Ibid, 151.
} 
images as a set of multiples enables the viewer to see beyond the "archive of the African diaspora and consequently to see (and to see it) differently." ${ }^{25}$ Hence, by attending to the seriality of Vietnamese vernacular photographs, I am able to interrogate how and why repetition exists for the community to create a sense of belonging and stability in the context of their lost nation.

Expanding on the idea of images producing a social network and viewing images as multiples, in The Public Image, authors Robert Hariman and John Lucaites aim to demonstrate how photographic images can help us rethink the publicness of society, politics and culture. ${ }^{26}$ The authors define spectatorship as a social relationship and civic capability in which spectatorship can provide a way of existing in the world with others. Noting that photography functions like a small language in that it is repetitive and used for representing the familiar, they consider photography as a dimension of abundance - a space in which similar images are circulated and seen by multiple people repeatedly. This is done through a "civic contract" created by each image that exists, a contract that is important because the fact that the image will be read again by others makes possible the connection of all viewers as virtual citizens. ${ }^{27}$ This virtual connection is critically important as photographs' multi-temporal quality have the potential to connect present day viewers to those of the past, therefore creating an imagined sense of community across time and space.

\section{Memory, Visibility and the Vietnamese Community}

While photographs can act as records demonstrating how diasporic communities construct identity and a sense of belonging, they also function as spaces to mediate memory

\footnotetext{
${ }^{25}$ Campt, Image Matters, 70.

${ }^{26}$ Robert Hariman and John Lucaites, The Public Image: Photography and Civic Spectatorship (University of Chicago Press, 2017), 6.

${ }^{27}$ Ibid, 69.
} 
between generations. In their co-written article "We Would Have Not Come Without You," memory studies scholars Marianne Hirsch and Leo Spitzer consider how memory invokes nostalgia and "the creativity of reconstruction." ${ }^{28}$ They note that the desire to recall negative and traumatic memories can call into becoming co-witnesses and therefore, facilitate a "process of working through." ${ }^{29}$ The authors observe two types of nostalgia, restorative and rootless, with the latter being in between temporalities and generations. They argue that this "in-betweenness" can stage traumatic memories and they note that children of refugees will inherit their parents' knowledge of the fragile and transient space. ${ }^{30}$ Hence, for the South Vietnamese community who also emerged from trauma, the photographs of their remembrance gatherings can conciliate postmemory and conjure nostalgia when 1.5 and second generation youth view these images.

Like Hirsch and Spitzer, Communication studies scholar Kim Nguyen explores the staging, or rather the restaging, of traumatic memories and how they are passed down to the next generation. In "Without the Luxury of Historical Amnesia," Nguyen argues that the community's employment of an anti-communist rhetoric rearticulates "bad" memories of the war into "good" or needed memories to rescue South Vietnam from communism. ${ }^{31}$ Through her analysis of the documentary Saigon, USA which follows the aftermath of the $1999 \mathrm{Hi}-T e k$ protests, Nguyen argues that there is a "constructed need to reproduce prewar Vietnamese values and traditions for the Vietnamese American generations to come.” ${ }^{32}$ The documentary shows that anti-communist protests also serve as a means for families to teach second

\footnotetext{
${ }^{28}$ Marianne Hirsch and Leo Spitzer, "We Would Not Have Come Without You: Generations of Nostalgia," American Imago 59, no. 3 (2002): 258.

${ }^{29}$ Hirsch and Spitzer, "We Would Not Have Come Without You: Generations of Nostalgia," 260.

${ }^{30} \mathrm{lbid}, 274$.

${ }^{31}$ Kim Nguyen, "Without the Luxury of Historical Amnesia": The Model Postwar Immigrant Remembering the Vietnam War Through Anti Communist Protests, "Journal of Communication Inquiry 34, no.2 (2010): 137.

${ }^{32}$ Nguyen, "Without the Luxury of Historical Amnesia," 138.
} 
generation youth the "right from wrong ideology." ${ }^{33}$ Therefore, Nguyen argues that the documentary reinforces prewar cultural practices, including maintaining the values of family organizing and preserving patriarchal power. ${ }^{34}$ I expand on the influence of Vietnamese cultural productions as I contend that photographs of the community are culturally disicliping youth, teaching them a specific Vietnamese identity.

Moreover, the intricacies of memory passing between generations are influenced and determined by the community's selective memory keeping. Vietnamese American studies scholars are exploring how the rhetoric of Vietnamese anti-communism affects and shapes the South Vietnamese diasporic community and their memories. For example, Ethnic Studies scholar Yến Lê Espiritu in Body Counts also notes how the primary political language of the Vietnamese refugees adopts an aggressively anti-communist stance. She argues that through this stance, refugees are able to be seen and understood within an American political and social climate. ${ }^{35}$ Espiritu analyzes the legacies of U.S. militarism and imperialism on the Vietnamese American community by critiquing the narrative of the refugee as a traumatized subject. She critiques how the Việt Nam War is often reduced into a single narrative, which focuses on American experiences, due to a historical amnesia that often removes the experiences of the Vietnamese peoples themselves. Espiritu argues that this purposeful forgetting repositions the U.S. as a benevolent, refugee-accepting nation. For the Vietnamese in the diaspora, however, Espiritu notes that their memories demonstrate that for them, the Việt Nam War is not over. Moreover, she also critiques how popular images of the Việt Nam War that display U.S. heroism and demonstrate a white saviour complex only tell half-truths, suggesting the need to consider images produced by Vietnamese to counter these popular narratives. ${ }^{36}$

\footnotetext{
${ }^{33}$ Nguyen, "Without the Luxury of Historical Amnesia," 141.

${ }^{34}$ Ibid, 140.

${ }^{35}$ Espiritu, Body Counts: The Vietnam war and Militarized Refuge(es), 96.

${ }^{36}$ Ibid, 34.
} 
In Little Saigons: Staying Vietnamese in America, American studies scholar Karin Aguilar-San Juan examines how "staying Vietnamese" involves encounters with the past, and with processes of racialization. The book defines community-building and place-making as purposely strategic tools that shift and affect ways of becoming Vietnamese. In her analysis of Little Saigon in Orange County, Aguilar-San Juan demonstrates how the social processes of history and memory can be used strategically to assert the social, political and spatial boundaries of a community. She argues that memory projects like displaying the freedom flag, monuments and anti-communist protests "monitors who belongs and attach symbolic weight to place.” While Aguilar-San Juan discusses these highly visual memory projects, very few photographs are used in her study. As noted by the author herself, she does not explore "the visual dimension of Vietnamese American community building and place making." ${ }^{38}$ Therefore, I will bridge this gap by analyzing photographs of community events during the first 15 years of resettlement and community building to explore how the community stays South Vietnamese.

In The American Dream in Vietnamese, Nhi T. Lieu also assesses how memories of pre-1975 South Vietnam are perpetuated through media consumption. ${ }^{39}$ By interrogating the politics of Vietnamese femininity and womanhood, Lieu illustrates the gendered labour of memory-keeping placed upon Vietnamese women through her critical analysis of pageantry and performances. Her work shows how an examination of media produced in the diaspora as well as community events can help determine how this media helps in honouring, remembering, and preserving select cultural memory and desires. Lieu's analysis provides a critical framework in examining the gendered performances and public displays of Vietnameseness imposed onto the younger generation.

${ }^{37}$ Karen Aguilar-San Juan, Little Saigons: Staying Vietnamese in America (University of Minnesota Press, 2009), 88.

${ }^{38}$ Aguilar-San Juan, Little Saigons, 145.

${ }^{39}$ Nhi T. Lieu, The American Dream in Vietnamese (University of Minnesota Press, 2011). 
Additionally, the (in)visibility of the South Vietnamese in the American narrative is explored in Returns of War: South Vietnam and the Price of Refugee Memory. In this book, Long T. Bui examines how "Vietnamization," a failed and flawed Cold War military strategy, lingers in the afterlife of war through the South Vietnamese diaspora. Bui examines how the history of South Vietnam, a lost nation, is maintained through the community's returns to memory. In the chapter, Militarized Freedoms: Vietnamese American Soldiers Fighting "Future Vietnams," Bui addresses the dangers of a historical amnesia that could potentially lead younger-generation Vietnamese American soldiers to blindly support American exceptionalism. ${ }^{40}$ Bui then explores how resisting historical amnesia, through the assertion and re-assertion of memory, can build a community and help it achieve visibility within the American narrative. Hence, by understanding the community's desire for visibility allows me to investigate how these desires exists through vernacular photographs and the implications of what these desires communicate to the younger generations.

Furthermore, Vietnamese in Orange County also examines the history of Little Saigon. This book by Asian American studies scholars, Thúy Võ Đặng, Linda Trinh Võ and Trâm Lê, provides an illustrative timeline of how the Vietnamese community formed in Orange County. ${ }^{41}$ Through the use of photographs paired with short descriptions, the authors provide insight into the unique experiences of the Vietnamese diaspora. In particular, the section, Little Saigon and Civic Engagement relates well to the discussions of strategic memory projects used for community-building and place-making as mentioned in Aguilar-San Juan's study. As I analyze photographs of community gatherings that were situated and possibly circulated in Little Saigon, this text provides a visual and historical lens on its development.

\footnotetext{
${ }^{40}$ Long T. Bui, Returns of War: South Vietnam and the Price of Refugee Memory (New York University Press, 2018), 155.

${ }^{41}$ Thuy Võ Đăng, Linda Trinh Võ, and Trâm Lê, Vietnamese in Orange County (Charleston, South Carolina: Arcadia Publishing, 2015).
} 


\section{Vietnamese American Visual Culture}

The visual culture of the war in Việt Nam is a topic taken up more directly in Marita Sturken's important book, Tangled Memories, which considers how national narratives are mediated through images. Sturken argues that images can produce both memory and amnesia as well as cultural memory and history. ${ }^{42}$ Sturken notes that the photographic image is equated to memory that can construct and deconstruct the past. Therefore, photographic images can be contested as they trouble memories of individuals and of a nation, particularly when they shift "discourses of history, personal memory ... and history making." ${ }^{43}$ Through monuments and memorials, Sturken examines how "taking part in reenactments" whether through watching or performing, entails participation in nation building. Sturken also notes how remembrance and "healing the wound" is done through imagery that creates a sense of participation in a collective memory or understanding of a significant or impactful event. This is a useful framework to build on for my examination of the role of images in the South Vietnamese diasporic community as these images are of commemorative events and performances, which are explicitly meant to remember quê hương, the homeland.

While Sturken examines images of the Việt Nam war, critics such as Tina Nguyễn, Thy Phu and Evyn Lê Espiritu consider Vietnamese visual media to examine the visual narratives that the diasporic Vietnamese community asserts about themselves. In "The Popular Media of the Vietnamese Diaspora," Tina Nguyễn and Stuart Cunningham examine how popular media created in the Vietnamese diaspora such as Paris By Night and music videos produced by the

\footnotetext{
42 Marita Sturken, Tangled Memories: The Vietnam War, the AIDS Epidemic, and the Politics of Remembering (Berkeley: University of California Press) 20.

${ }^{43}$ lbid, 45.
} 
studio Thuy Nga, exhibits "pure" heritage maintenance and ideological monitoring. ${ }^{44}$ They argue that music and other media like Vietnamese newspapers maintain an anti-communist stance by employing nostalgia and, therefore, primarily serve the needs of first wave Vietnamese immigrants. They also highlight that the media use of the Vietnamese diasporic community is fundamentally different from other cultural groups as its production is centered within the diaspora rather than the "home" country. Because the photographs of my case studies were created in proximity to Little Saigon, the center of Vietnamese diasporic media, I contend that we see traces of the media shaping 1.5 and second generation's visual understanding of a Vietnamese identity through images of student led performances.

Moreover, in the essay "Diasporic Vietnamese Family Photographs, Orphan Images, and the Art of Recollection" Phu explores how family photographs have shaped and affected the Vietnamese diasporic community. ${ }^{45}$ Phu suggests that examining family photography can counteract the well-known violent visual narratives of the war and aims to establish a better understanding of the multiple layers of the Vietnamese vernacular image. To do so, Phu explores its creation and its preservation, whether that be its physical existence or its existence through memory.

Expanding on this, Evyn Lê Espiritu examines vernacular images that circulate online. In "Who was Colonel Ho Ngoc Can?" ${ }^{46}$ Espiritu argues for a queer and feminist reading of commemorative online visual materials produced by first generation, male, Vietnamese veterans of the South Vietnamese Army of the Republic of Vietnam (ARVN). When learning the history of her great uncle, a celebrated ARVN colonel who was publicly executed, Espiritu found

\footnotetext{
44 Tina Nguyễn and Stuart Cunningham, "The Popular Media of the Vietnamese Diaspora," Media International Australia, Incorporating Culture \& Policy no. 91 (1999).

${ }^{45}$ Thy Phu, "Diasporic Vietnamese Family Photographs, Orphan Images, and the Art of Recollection," Trans Asia Photography Review 5, no.1 (Fall 2014): http://hdl.handle.net/2027/spo.7977573.0005.102. ${ }^{46}$ Evyn Lê Espiritu, "Who Was Colonel Ho Ngoc Can? Queer and Feminist Practices for Exhibiting South Vietnamese History on the Internet," Amerasia Journal 43, no.2 (2017): 3-24.
} 
numerous websites, blogs and YouTube videos created in his memory for his bravery and resistance to the communist government. She calls this realm of online preservation a diasporic refugee archive, existing as both a noun and verb. Espiritu determines that the forced and organized forgetting of South Vietnamese national history and erasure of ARVN subjectivity in the state archive (both in the United States and Vietnam) prompts these men to create and assert agency of their narratives online. Her article illustrates the masculinist and patriarchal narratives employed by first generation Vietnamese men to remember. As opposed to looking solely at men's assertion of masculinist and patriarchal identities, I will analyze how and why the gendered labour of public performance and memory keeping are imposed onto young Vietnamese American women.

\section{The Teachings of the Past in the Paul Tran Files}

As my literature review suggests, ideas of Vietnameseness are maintained and reproduced through vernacular photographs of community events. What methods of memory preservation and memory transmission did the first generation employ during the earliest years of resettlement? This section examines a case study of six curated images illustrating members of the first generation of the South Vietnamese diaspora gathering for remembrance and commemoration through performance. It also explores how this community subsequently displays these images and considers how the images informed the 1.5 generation's understanding of a Vietnamese identity.

The selected photographs are from the "Paul Tran Files on Southeast Asian refugees," a collection donated by Paul Tran between 1993-95. Tran, a Vietnamese-American community activist and former University of California Irvine (UCI) student, collected a variety of materials including correspondence between Vietnamese associations, artifacts, audio recordings of 
refugee interviews, and Vietnamese periodicals. The collection consists of 29 boxes, 16 of which are currently restricted, and is organized into four series: Vietnamese refugee camps files (1976-2001), subject files concerning refugee issues (1976-2001), refugee artwork (1980-1985), and newspapers and clippings (1975-1996). ${ }^{47}$ Because access to a number of boxes was restricted, I was limited in terms of what I could obtain for research. However, based on the collection guide, all photographs were listed in Box 4 and found in folders 19-25. Together, the six folders contained over 200 photographs in colour and black and white.

The images I selected are from folders 19 and 23, labelled "Camps, circa 1980-1990" and "Miscellaneous 1980-1994" respectively. These photographs moved me because they documented community commemorative performances I was familiar with, even though I did not grow up in Southern California. They illustrate a group of first generation South Vietnamese refugees participating in musical performances in Orange County in the early 1980s, just less than 10 years following the Fall of Saigon on April 30, 1975. The freedom flag or heritage flag, as it is also known, is present in each selected photograph, and is easily recognizable by its yellow background contrasted with three red stripes. The heritage flag is a potent visual signifier of the South Vietnamese diasporic community as a symbol of nationalism that also denotes democracy and freedom. Its prominent visibility in the diaspora is used to invoke a historical past before communism that members of the first generation are keen to revive.

As Aguilar-San Juan notes, strategic memory projects such as prominently displaying the heritage flag is a method of monitoring who belongs and is a "purposeful effort to construct and produce memory in such a way as to reinforce this sense of belonging." ${ }^{48}$ As the freedom flag symbolizes a strong rejection of communism and anchors the community's identity within an

\footnotetext{
47 "Paul Tran Files on Southeast Asian refugees. MS-SEA002," Special Collections and Archives, The UC Irvine Libraries, Irvine, California, accessed March 11, 2019, https://oac.cdlib.org/findaid/ark:/13030/tf8f59p1tg/dsc/\#dsc-1.8.7.

${ }^{48}$ Aguilar-San Juan, Little Saigons, 131.
} 
anit-communist rhetoric. Moreover, Aguilar-San Juan elaborates further that staying Vietnamese entails

establishing roots in the form of an actively remembered though vigorously debated past...Vietnamese Americans are employing memory practices in particular ways so as to reinforce strategically their own rules about who belongs within the boundaries of community and place.

Hence, the events depicted in the photographs are strictly for the South Vietnamese diaspora as they reinforce political and spatial boundaries through the remembrance of South Việt Nam.

While sifting through the images in the collection, I was struck by these banal photographs because I had seen, felt and heard them before. Photographs of men and women on stage singing and dancing in traditional Vietnamese clothing and photographs of gatherings with the heritage flag proudly on display, exist in my own family's personal collection. It immediately intrigued me that these images from the 1980s of the Vietnamese American community in Southern California were, in fact, not that different from images of the Vietnamese Canadian community in my hometown from the same era. I was moved by their similarities and the very action of men and women, whether in the Vietnamese Canadian or Vietnamese American diaspora, gathering together to claim and reclaim space, history and their culture.

These similarities can in part be explained through the overlapping timelines invoked in the photographs. As a spectator to the selected photographs today, they are remarkable as multi-temporal artifacts. That is, they have an affective register of haptic temporality, a term coined by Tina M. Campt as multiple forms of contact, which "create alternative modalities for understanding the archival temporalities of images." ${ }^{50}$ The photographs are, in other words, multi-temporal because viewing them today in 2019, these images do not just evoke the 1980 s,

\footnotetext{
${ }^{49}$ Aguilar-San Juan, Little Saigons, 64-66.

${ }^{50}$ Tina M. Campt, Listening to Images (Durham and London: Duke University Press, 2017), 72.
} 
at the moment they were taken. In fact, they evoke an even earlier temporality-specifically prior to the Fall of Saigon in 1975.

They conjure, then, a sense of rootless nostalgia, a feeling that children of refugees inherit from their parents' memories, one that hearkens to a transient experience that they themselves would not have any direct knowledge of, as noted by Marianne Hirsch. ${ }^{51}$ Rootless nostalgia derives from postmemories that children inherit from their parents. Such postmemories are mediated by numerous channels such as "stories, images and behaviours." ${ }^{2}$ Likewise, Hirsch asserts that,

postmemory's connection to the past is thus actually mediated not by recall but by imaginative investment, projection and creation... [it is] a structure of inter- and transgenerational return of traumatic knowledge and embodied experience.

Hirsch continues that visual media like photography can conciliate this inherited knowledge. ${ }^{54}$ Thus, the images depicting South Vietnamese refugees and commemorative events in the 1980s act as transient spaces for postmemory transmission between generations across the past, present and future.

Furthermore, the photographs in this selection from the Tran collection perform multiple functions. Not only is music re-performed, but anti-communist ideologies are also re-performed, as evident by the existence of the heritage flag on display. In this way, memory and nostalgia are re-performed as well. I believe that these multiple choreographies exist by the very fact that these mundane images have several haptic temporalities. These repeated performances continue across such temporalities because of a historical amnesia that continues to exist in the dominant narrative surrounding the Việt Nam war. This enforces an invisibility onto the

\footnotetext{
${ }^{51}$ Hirsch and Spitzer, "'We Would Not Have Come Without You": Generations of Nostalgia," 274.

52 Ibid, 256-262.

${ }_{53}$ Marianne Hirsch, The Generation of Postmemory: Writing and Visual Culture After the Holocaust (New York Colunbia University Press, 2012): 4-6.

${ }^{54}$ Hirsch, The Generation of Postmemory, 4-6.
} 
Vietnamese peoples experiences of the war. With such little room to be seen or heard, I contend, only a specific sense of Vietnameseness becomes visible — a South Vietnameseness.

As discussed earlier, the Vietnamese American community defines its identity by embracing a conservative, Cold War rhetoric. ${ }^{55}$ For this reason, the community's ideal Vietnameseness is one that is rooted in an anti-communist rhetoric and tied to an imaginary of South Việt Nam or "old" Việt Nam. ${ }^{56}$ As Long T. Bui states, the Việt Nam war dictated the subject, history and demise of South Việt Nam assuming April 30, 1975 as marking both the end of the war and the end of South Việt Nam. ${ }^{57}$ Bui notes that if 1975 marks the end, then "the subject of South Việt Nam should be dead or put to rest." ${ }^{58}$ However, as evident in photographs of this case study, the subject of the lost nation is certainly not dead or forgotten. The first wave of the first generation attempt to resurrect South Việt Nam and a selective memory of the homeland before communism. Therefore, for this particular community, staying Vietnamese means staying South Vietnamese and anti-communist. Since the photographs are of commemorative events which already perform a selective remembering, the photographs themselves mediate particular kinds of memories to the younger generation.

As the next section will demonstrate, I examine the set of photographs in three pairs. The first pair is from the same concert event, whereas the next pair illustrates two groups from different celebrations potentially performing the same song. The last set exhibits intergenerational performances.

\footnotetext{
${ }^{55}$ Espiritu, Body Counts, 96.

${ }^{56}$ Bui, Returns of War: South Vietnam and the Price of Refugee Memory, 17. Note: Diacritical marks added.

57 Ibid.

$58 \mathrm{lbid}$.
} 


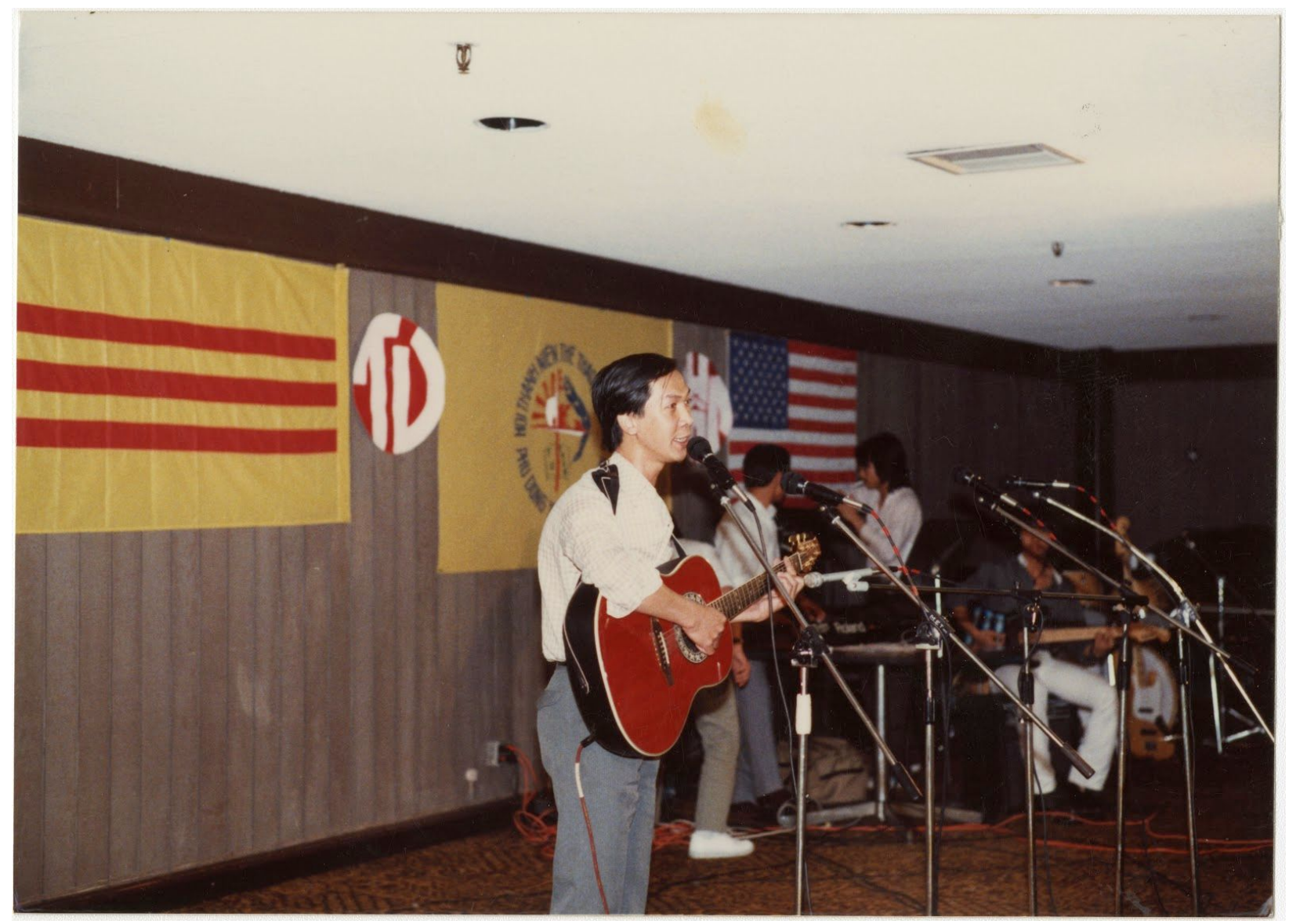

Figure 1. Trường Nguyễn strumming a guitar (c.1980)

Image Courtesy of UCI Libraries Special Collections, Southeast Asian Archive from the Paul Tran Files, MS-SEA002_b04_f19.

\section{Music and Memory}

As noted above, the first two photographs are from the same event as evident by the verso description of văn nghệ, meaning concert. ${ }^{59}$ They also share visual similarities, as behind the performers, the freedom flag and the banner of a Vietnamese association are displayed on a dark brown wooden wall. These details suggest that these images were taken by the same photographer but from different angles. In the first photograph, a man identified as Trường Nguyễn, strums a guitar while singing into a microphone (fig.1). The second photograph depicts the musical performers, Cao Tôn Kháng playing the flute and Thúy Hiền donning a red áo dài, a

${ }^{59}$ See Figure 1a. and Figure 2a. in appendix. 
Vietnamese traditional dress, while also singing into a microphone at the same time that she looks at her stage partner (fig. 2).

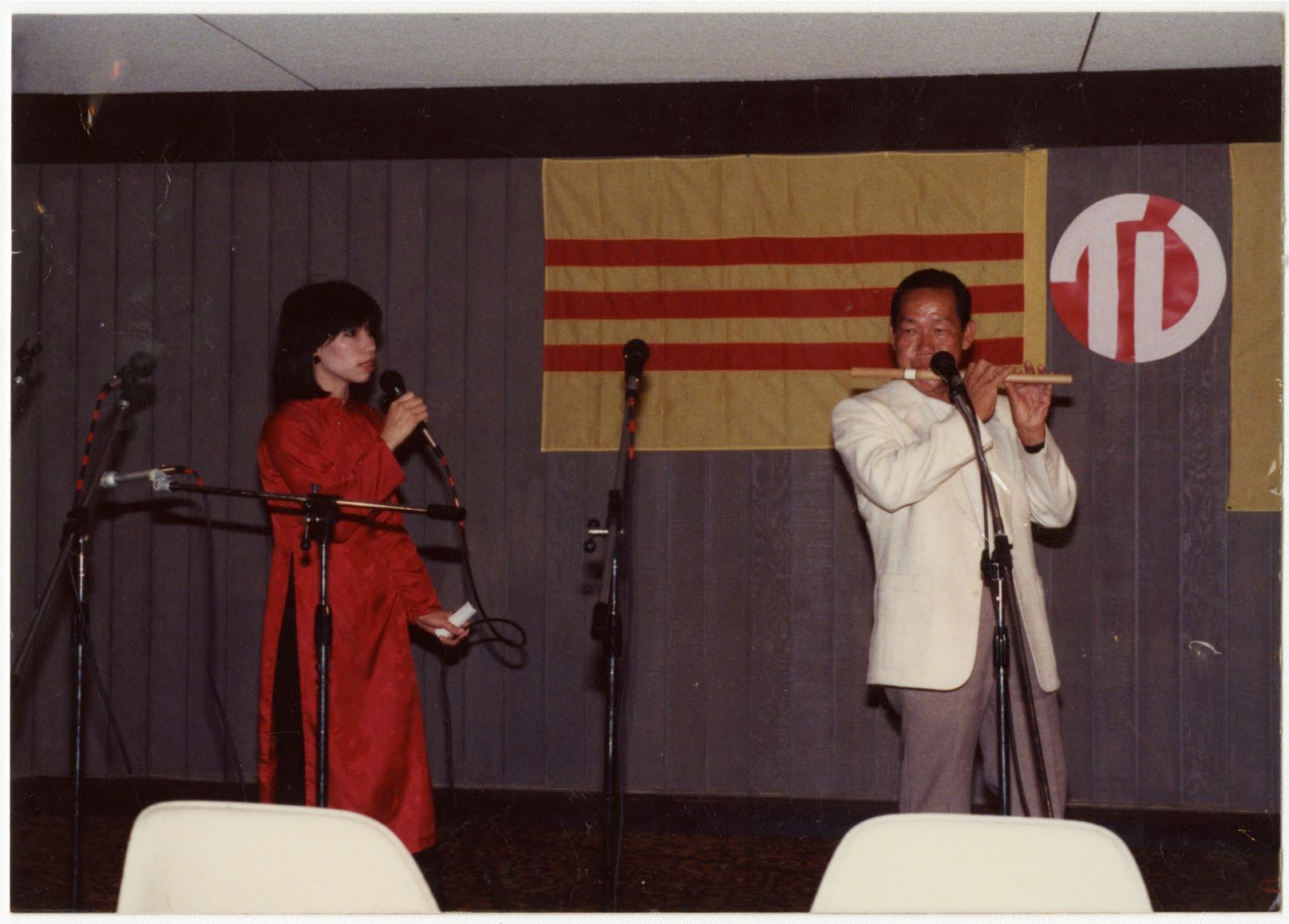

Figure 2. Cao Tôn Kháng and Thúy Hiền performance (c.1980)

Image Courtesy of UCI Libraries Special Collections, Southeast Asian Archive from the Paul Tran Files, MS-SEA002_b04_f19.

The specific songs they are performing are not indicated on the verso. Nevertheless, they can be heard. Not only do they transport us back, visually, to South Việt Nam but they also evoke nhạc tiền chiến or nhạc trước '75-that is, music from before the end of the war and therefore, before, 1975. This period is pivotal because it is one that the first generation seeks to revitalize and establish as the norm for the diasporic community in the early years of resettlement. Due to the fact that these banal images depict community events with music, this 
pair and the other photographs also act as tools of "pure" heritage maintenance. As noted by Tina Nguyễn and Stuart Cunningham, pure heritage maintenance entails an "ideological monitoring role of maintaining the salience of the anti-communist stance foundational to the diaspora." lies in the restoration and preservation of traditional Vietnamese music style," one that is consumed by the older and elite generation. ${ }^{61}$

Moreover, in Listening to Images, Campt suggests that, when looking to the banal and mundane photographs, we need to listen to "lower frequencies." ${ }^{62}$ It is in these lower frequencies that she theorizes sound as an inherently "embodied processes that registers at multiple levels... sound need not to be heard to be perceived." ${ }^{63}$ We need, then, to look not just at the visual dimensions of images, but also to attend to "the other affective frequencies through which photographs register." ${ }^{64}$ These photographs of performances conjure the sounds and music specific to the South Vietnamese diaspora. Because these images are multi-temporal, the subjects of the photographs are performing and re-performing this music and both the ideologies and the desires of the community, for the present-day viewer.

Additionally, Nguyễn and Cunningham state that music "circulates as a commodity in the marketplace" and it helps in the dual function of cultural maintenance and adoption. ${ }^{65}$ Put simply, nhạc trước '75 helps relieve some of the pain of homesickness by employing and exploiting a particular nostalgia for pre-1975 South Việt Nam. Prior to the fall of Saigon, Saigonese music developed in ways that mixed French and Western influence. This music included love songs and songs about resistance and independence, which appealed to the

\footnotetext{
${ }^{60}$ Nguyễn and Cunningham, "The Popular Media of the Vietnamese Diaspora," 136.

${ }^{61} \mathrm{lbid}, 137$.

${ }^{62}$ Campt, Listening to Images, 6.

${ }^{63}$ Ibid.

${ }^{64} \mathrm{lbid}, 9$.

${ }^{65}$ Nguyễn and Cunningham, "The Popular Media of the Vietnamese Diaspora," 125.
} 
older generation. ${ }^{66}$ Likewise, in The American Dream in Vietnamese, Nhi T. Lieu examines how the company "Paris By Night" produced extravagant musical performances for the Vietnamese diaspora, noting that this particular genre of music, nhạc trước '75, is popular amongst the first generation as it revitalizes their memories of old Việt Nam. ${ }^{67}$ As Caroline Kiều Linh Valverde also asserts, "the songs are nationalistic in nature and carried with them images of a glorious past and a hope of returning to the homeland." ${ }^{68}$

The next pair of images also invoke this genre of music (fig. 3,4). They both illustrate a group of first generation Vietnamese Americans singing. The two photographs are similarly composed, for the subjects are centered on stage. Furthermore, there is visual resemblance in the subjects depicted as the women are wearing áo dài and holding folders with the freedom flag printed on it close to their bodies, while men are in the back rows. The obvious visual differences is that one is a colour $4 \times 6$ photograph and depicts a group of 24 , and the other is a $2 \times 4$ black and white photograph of a smaller group of 18 .

${ }^{66}$ Caroline Kiều Linh Valverde, "Making Transational Viet Nam: Vietnamese American Community — Viet Nam Linkages through Money, Music and Modems" (PhD diss., University of California Berkeley, 2002), 148.

${ }^{67}$ Lieu, The American Dream in Vietnamese, 81.

${ }^{68}$ Kiều Linh Valverde, "Making Transational Viet Nam," 164. 


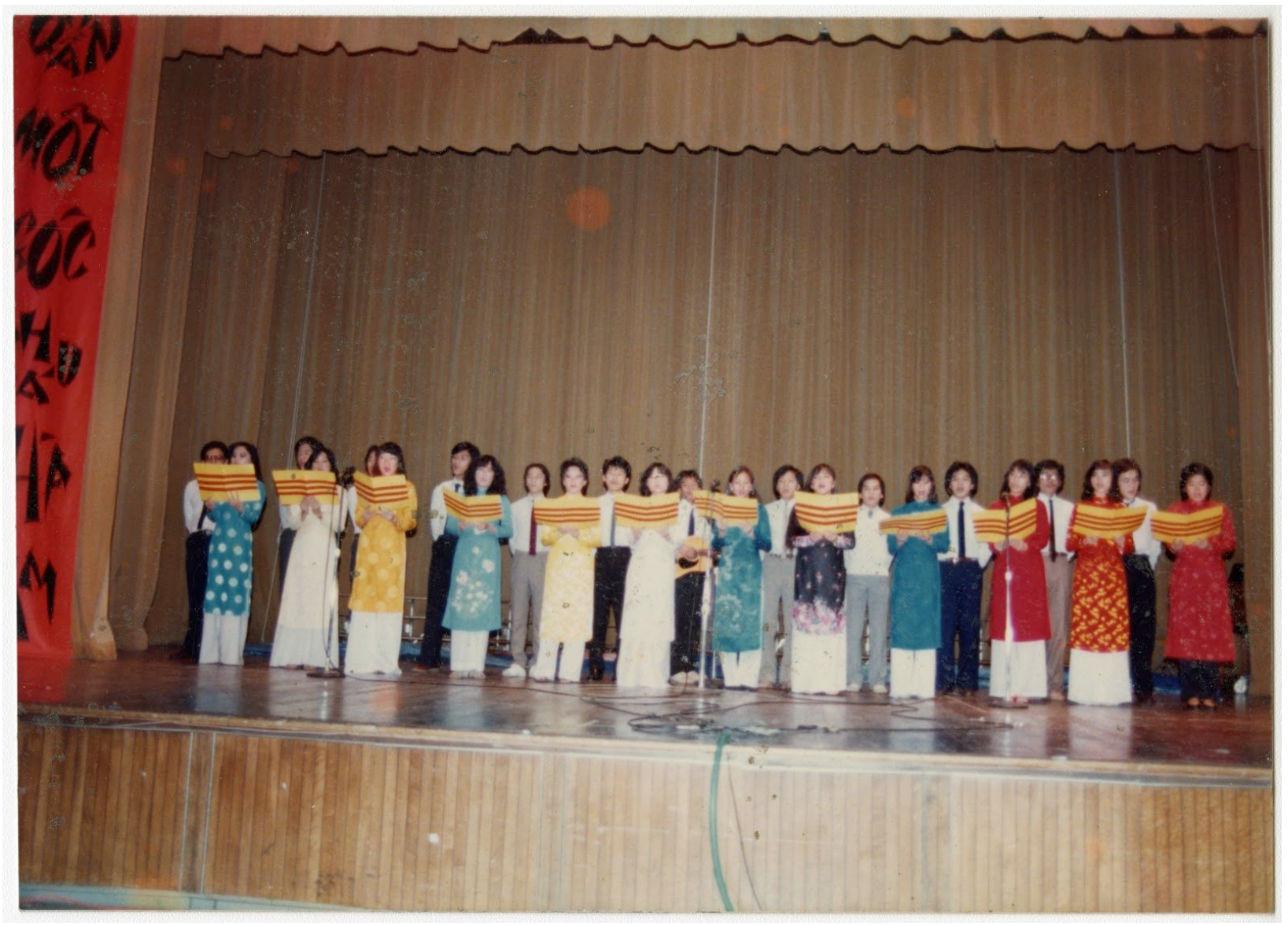

Figure 3. UCLA choir performance of "Ly Rượu Mùrng" (c.1980)

Image Courtesy of UCI Libraries Special Collections, Southeast Asian Archive from the Paul Tran Files, MS-SEA002_b04_f23.

The colour photograph illustrates a choir group from the University of California Los Angeles (UCLA) performing the song "Ly Rượu Mừng," loosely translated to "A Glass of Wine." It is a song performed to welcome everyone to a Tết, or Lunar New Year, celebration.

Composed by Phạm Đình Chương in 1952, the song was first performed by the musical group Thăng Long. ${ }^{69}$ The song is a cheerful, celebratory song to lift one's hopes and spirits during the war. However, the line:

“Hát khúc hoan ca thắm tươi đời lính

${ }^{69}$ long vuong viet, "this song to be sing every Lunar New Year of South Viet Nam not north viet nam," YouTube comment, January 2019, https://www.youtube.com/watch?v=-zGQ2qVsCwQ. 
Sing the joyful song of the soldier, ${ }^{70}$

supposedly led the Communist government to ban the song following 1975 due to the controversy surrounding the term "soldier." ${ }^{71}$ One YouTube commenter made clear that this song was only sung in South Việt Nam during Tết. ${ }^{72}$

Thus, this image illustrates a choir group of first generation South Vietnamese singing a song that was likely played throughout their youth and which they remembered from before the war ended. Through this act, they draw a boundary and monitor who else can share in their reclamation of space and memory. To sing a song that was banned in their homeland and to perform it during their earliest years of resettlement in Southern California is a significant gesture indicating the first generation's desire to adamantly hold on to their South Vietnamese heritage.

\footnotetext{
${ }^{70}$ Phạm Đình Chương, Ly Rượu Mừng (1952), https://www.youtube.com/watch?v=CF2R2yJ--V8.

71 "A glass of wine," Wikipedia, accessed April 15, 2019, https://translate.google.com/translate?hl=en\&sl=vi\&u=https://vi.wikipedia.org/wiki/Ly_r\%25C6\%25B0\%25 E1\%25BB\%25A3u_m\%25E1\%25BB\%25ABng\&prev=search.

${ }^{72}$ After listening to this song on YouTube it became clear that I definitely witnessed my elders perform this song at Tết celebrations in Toronto, Canada.
} 


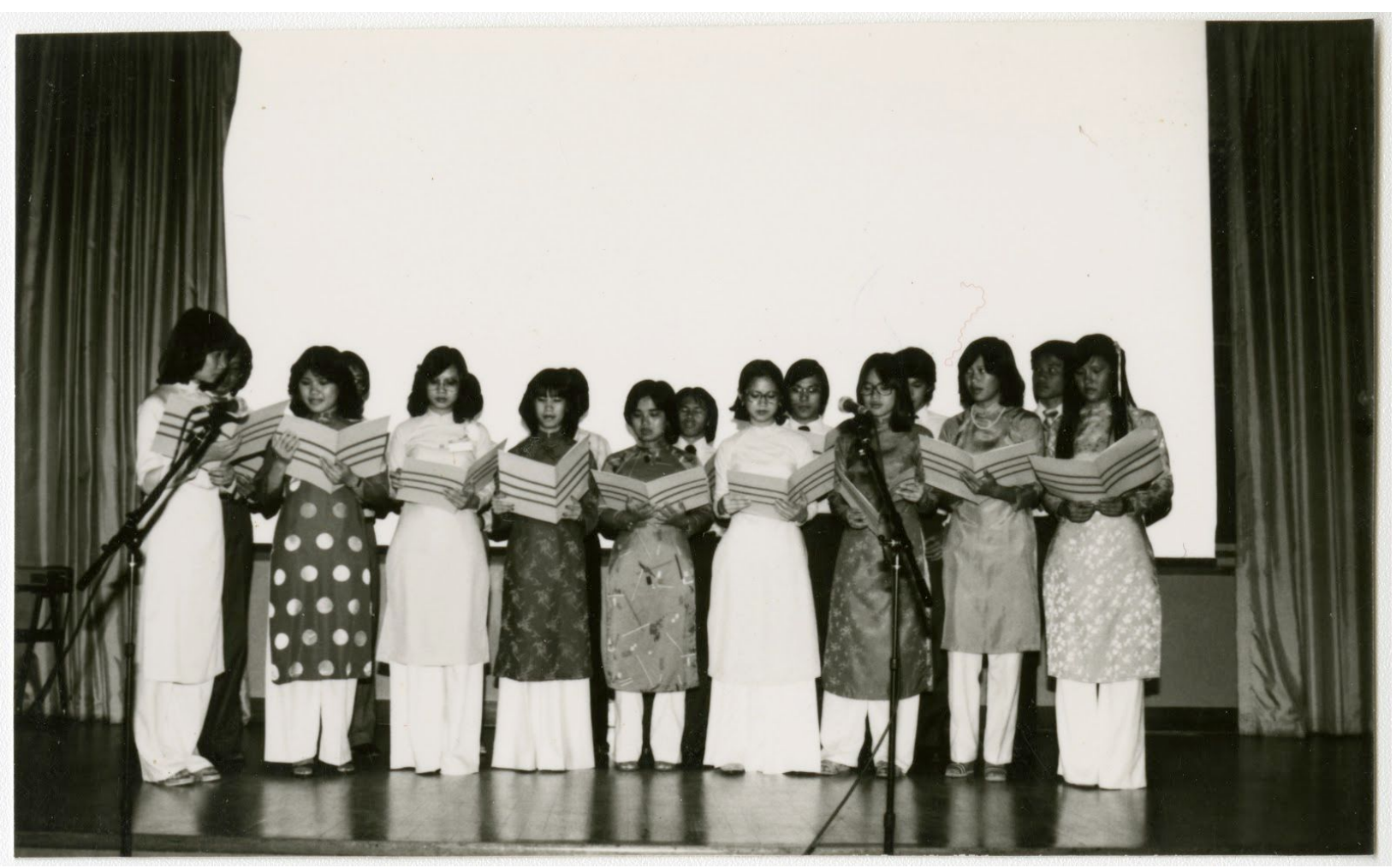

Figure 4. Choir performance (c.1980)

Image Courtesy of UCI Libraries Special Collections, Southeast Asian Archive from the Paul Tran Files, MS-SEA002_b04_f23.

Returning to figure 4, while there is no doubt that the group is also singing, it is not clear whether this choir sings the same song. Though it does not have a written caption on the back other than the number " 2 ," judging by the similarities in the style of the traditional dress, hairstyles and glasses that the women are wearing, it is likely the photograph also belongs to this early resettlement period of the $1980 \mathrm{~s} .{ }^{73}$ Regardless of the song that is sung, what is clear is that community members strove to stay South Vietnamese through such performances.

\section{Intergenerational Spectatorship and Participation}

When I initially encountered this pair of images, I assumed that they were performing the national anthem of South Việt Nam. While they are in fact not doing so, it is likely, however, that

\footnotetext{
${ }^{73}$ See Figure 4a. in appendix.
} 
the anthem was certainly sung at one point in the concert and at the Tết celebration. ${ }^{74}$ Together, the first four images in this case study prompt me to return to my earlier questions: What does it mean for these images to be created during the earliest years of resettlement in the United States? What selective, collective memory are they keeping and performing? And who are they performing for?

Certainly, the men and women perform for each other and the other first generation adults in the audience at the time of the event. And while not explicit, they are also performing for the youth—the 1.5 generation—who are likely attending the event with their parents. Again, the 1.5 generation refers to those who were born in Việt Nam and arrived to America at a young age after $1975 .{ }^{75}$ The very presence of the 1.5 generation at such events is critical because they would have been too young to have direct memories of the homeland.

What does it mean, then, for these youth to listen to nhạc trước '75? While such music is nationalistic and meant to illustrate a glorious past, it also demonstrates the first generation's hopes of and for the homeland. These hopes include returning to and reviving South Việt Nam in America through remembrance. Therefore, the pedagogical functions of these musical performances illustrate what the youth of the 1.5 generation must remember about their homeland.

Moreover, the performances and photographs of these performances, are crucial as they also serve to inform and shape these youth's ideas of Vietnamese identity — or specifically, a South Vietnamese identity that is rooted in maintaining this glorified past. As Marita Sturken notes in Tangled Memories, public commemorative symbols contribute to nation building. Thus, as illustrated in this case study, all participants, whether performers or

\footnotetext{
${ }^{74}$ I have attended Têt celebrations both in Toronto and Little Saigon where the national anthem is always been performed at the beginning of the ceremony.

${ }^{75}$ Thanh Hai Le Cao, "Crafting a New Self in the Diaspora: A Study of the 1.5 Generation of Vietnamese Americans" (PhD diss., University of Kansas, 2013), 2-3.
} 
spectators, contribute to nation and identity building. It is important for the 1.5 generation to be present at such events because as these youth become photographed and then look at such photographs, they can continually re-experience the first generation's teachings through postmemory. Therefore, the photographs themselves build multi-temporal and intergenerational spaces for the transmission and preservation of memory.

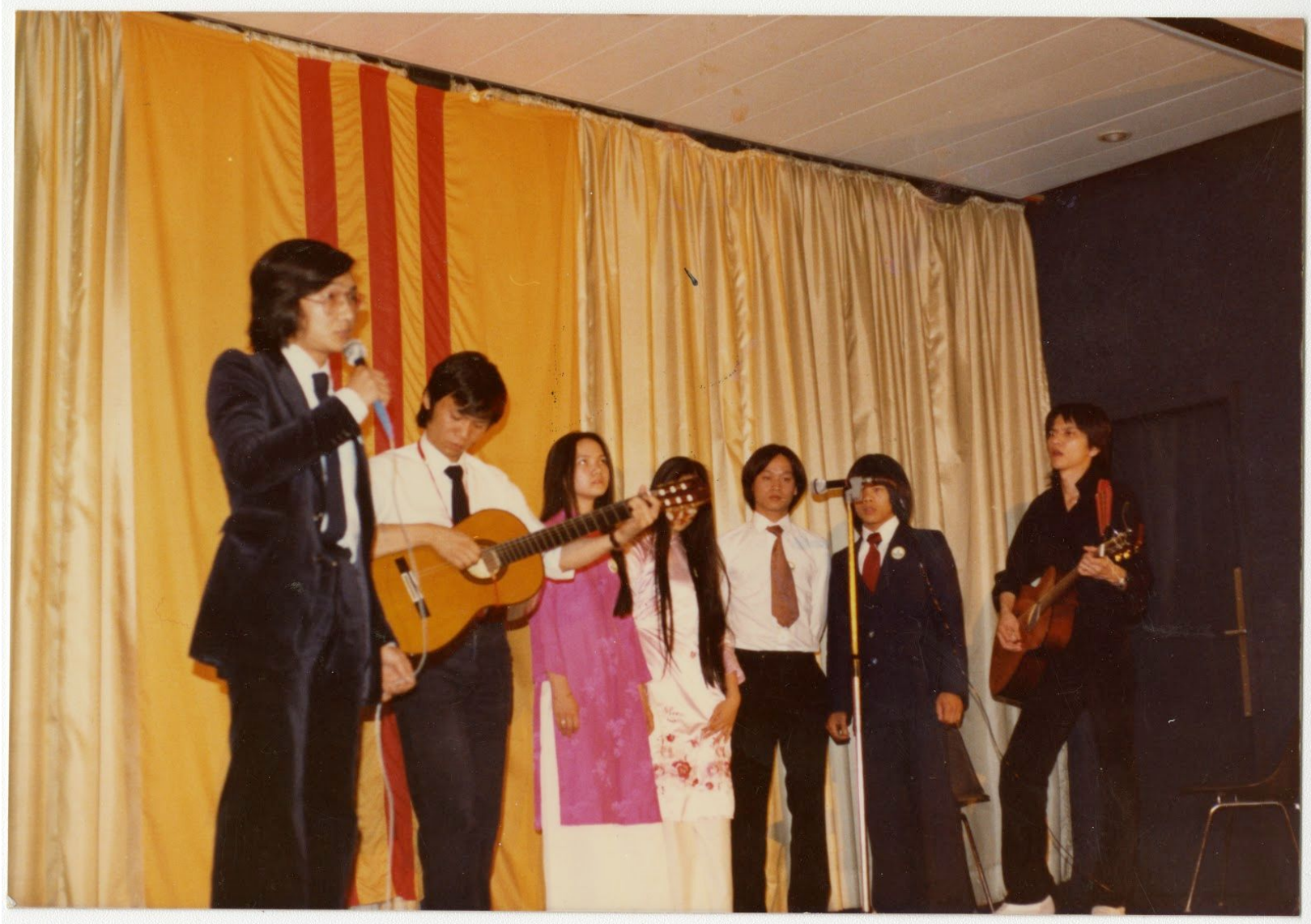

Figure 5. Vương Giao and youth performance (c.1980) Image Courtesy of UCI Libraries Special Collections, Southeast Asian Archive from the Paul Tran Files, MS-SEA002_b04_f23.

In figure 5, a man to the left with a group of youth made up of two girls in pink áo dài and four boys who are formally dressed with ties, are singing with the heritage flag on display behind them. Two boys are strumming guitars and the verso description translates to "Vương Giao and 
his friends performing." ${ }^{76}$ While we do not know what song they perform, nevertheless, this young group performs the nostalgia of their parents. Memory and cultural values are exchanged through this intergenerational performance of nhạc trước '75. This collaborative performance teaches youth to embody and carry forward a Vietnameseness, as defined by the older generation of refugees in the community.

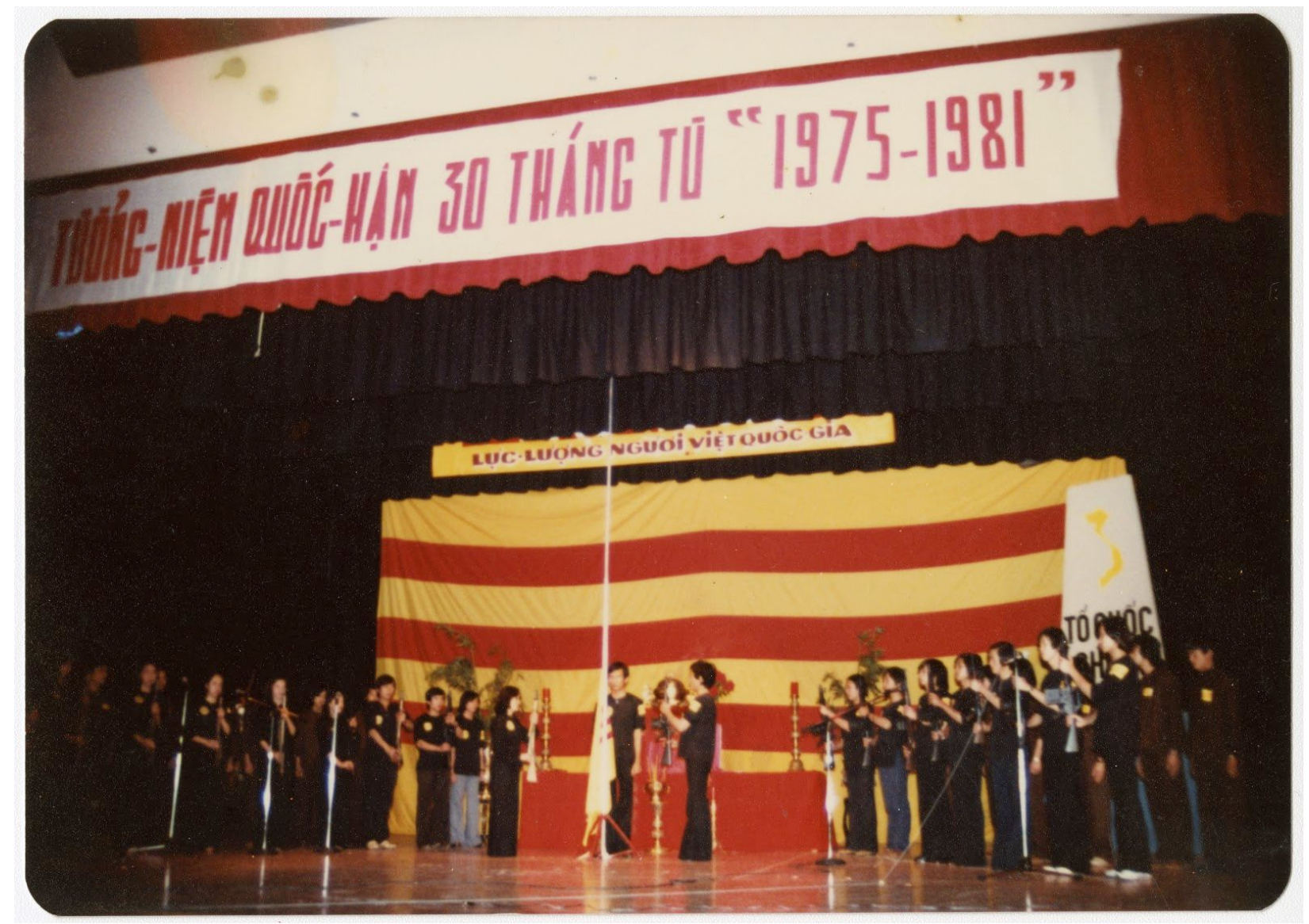

Figure 6. Youth commemorating April 30th (1981)

Image Courtesy of UCI Libraries Special Collections, Southeast Asian Archive from the Paul Tran Files, MS-SEA002_b04_f23.

Notably, a greater number of youth are only present in the last photograph, which also has the largest display of the heritage flag (fig.6). A large white banner hung above the stage

\footnotetext{
${ }^{76}$ See Figure 5a. in appendix.
} 
loosely translates to "Remembering April 30, 1975" with a smaller, yellow banner presenting the "Vietnamese Nationalist Forces." Here, youth participate by standing in for and paying respect to family members who fought with the South Vietnamese Army of the Republic of Vietnam (ARVN). They stand in black, each holding a gun upright with their gazes towards the two youth in the center of the stage, standing and waiting to raise the heritage flag.

Why would this tribute be significant to the community? Việt Thanh Nguyễn poignantly states, "all wars are fought twice, the first time on the battlefield, the second time in memory." The youth in the last pair of photographs actively engage and participate in such strategic memory projects (signing nhạc trước '75, wearing traditional clothing, engaging in other commemorative ceremonial traditions etc.). They are in a sense, fighting the war for the first time in postmemory, through rootless nostalgia. As the community events continue and performances are re-staged, youth will fight the war through this dimension multiple times.

By analyzing these vernacular photographs from the early ' 80 s closely, the first generation's (in)visible desires of resurrecting South Việt Nam unfolds. The community's anti-communist political stance is clearly apparent through the display of the heritage flag and performance of music from before 1975. Bui elaborates on this Cold War rhetoric which embodies the first generation's enduring belief that the war is not done, an act of refusal by the war generation to fall off the public radar... [hence] anti-communism keeps them and their history alive by producing a kind of "preservation discourses" that maintains their cultural integrity and authority at all costs.

The first generation's selective memory keeping and maintenance creates a collective identity rooted in this rhetoric for the Vietnamese American community. This selective, collective memory and the desires to not forget or be forgotten become mediated in the physical spaces of public events and again through their photographs. The commemorative events organized by

\footnotetext{
77 Việt Thanh Nguyễn, Nothing Ever Dies (Harvard University Press, 2016), 4.

${ }^{78}$ Bui, Returns of War, 107-108.
} 
the first generation, however, creates a battle between multiple memories for the 1.5 generation who have to negotiate their own memories of the homeland and the postmemories of their parents and of the broader diasporic community. Additionally, as the final pair in this case study illustrates, youth physically share the stage with the older generation, or, as is the case for the last photograph, stand in for their elders to perform in their memory. They too, contribute to the construction and preservation of a Vietnamese identity in the diaspora. Furthermore, while these events are done as a result of losing one's nation, these staged performances enable both the first and the 1.5 generation to imagine otherwise. To imagine, that is, a victory where South Việt Nam exists and to imagine never having to leave their homeland in the first place.

\section{Youth Performing and Carrying the Past From the Project Ngoc Records}

The second set of images I analyze-and the focus of this section-are from the Project Ngọc Records. Project Ngọc, meaning Project Pearl, was a humanitarian group run by UCI students who organized events and fundraisers to raise awareness of Southeast Asian refugee issues between 1987-1997. The Project Ngọc Records contain 11 boxes and 9 oversized folders arranged into five series: subject files concerning refugee issues (1978-1997), organizational files (1987-1997), visual and audiovisual materials (1985-1997), artwork (1987-1997) and newspaper clippings (1980-1998). ${ }^{79}$

As I continued looking through hundreds of colour photographs, the feeling of familiarity settled in once more. I was drawn again to community performances. However, these were choreographed by 1.5 and second generation students. As stated in Project Ngọc's mandate, the students hoped "to stand side by side the Vietnamese community abroad in assisting those

\footnotetext{
79 "Guide to Project Ngoc Records, MS-SEA016" Special Collections and Archives, The UC Irvine Libraries, Irvine, California, accessed, March 19, 2019, https://oac.cdlib.org/findaid/ark:/13030/kt8z09p8pd/.
} 
who are less fortunate than us and who are suffering daily in refugee camps in Southeast Asia." 80 The students are clear in wishing to return the "gift of freedom" by helping their community and those still seeking asylum. ${ }^{81}$ As was the case in the previous section, the photographs here share similar strategic memory projects used by the community. Most notably, sartorial displays of the áo dài and áo bà ba, a traditional Vietnamese shirt known for its humble simplicity. While I looked through folders documenting the organization's multiple community events, it became apparent that such displays are explicitly performed by young women. How and why are these memories of South Việt Nam in the diaspora being carried by women?

The selected photographs from the collection illustrate a văn nghệ 20 years following the Fall of Saigon. Held on November 19, 1995 in Santa Ana, California, the event titled, "Giọt Nước Mắt Cuối Cùng" meaning, "One Last Cry" was organized by Project Ngọc in collaboration with the Vietnamese Refugee Aid Committee (VRAC), a sub-committee formed by the Vietnamese Student Association (VSA) at UCLA in $1978 .^{82}$ VRAC was formed in order to meet the resettlement needs of the large influx of Vietnamese. As of the early 1990s, there were nearly 614,547 Vietnamese refugees in California and about 453,363 of which resettled in Southern California including Los Angeles and Orange County areas. ${ }^{83}$

\footnotetext{
${ }^{80}$ Project Ngọc and VRAC-UCLA, Giọt Nước Mắt Cuối Cùng Chương trình (One Last Cry program pamphlet), 1995: 1.

${ }^{81}$ See Mimi Thi Nguyễn's The Gift of Freedom: War, Debt and Other Refugee Passages.

82 "History," Vietnamese Student Union Bruins, accessed May 1, 2019, http://www.vsubruins.com/about/history/. ${ }^{83}$ Project Ngọc and VRAC-UCLA, Giọt Nước Mắt Cuối Cùng Chương trình (One Last Cry program pamphlet),1995: 3.
} 


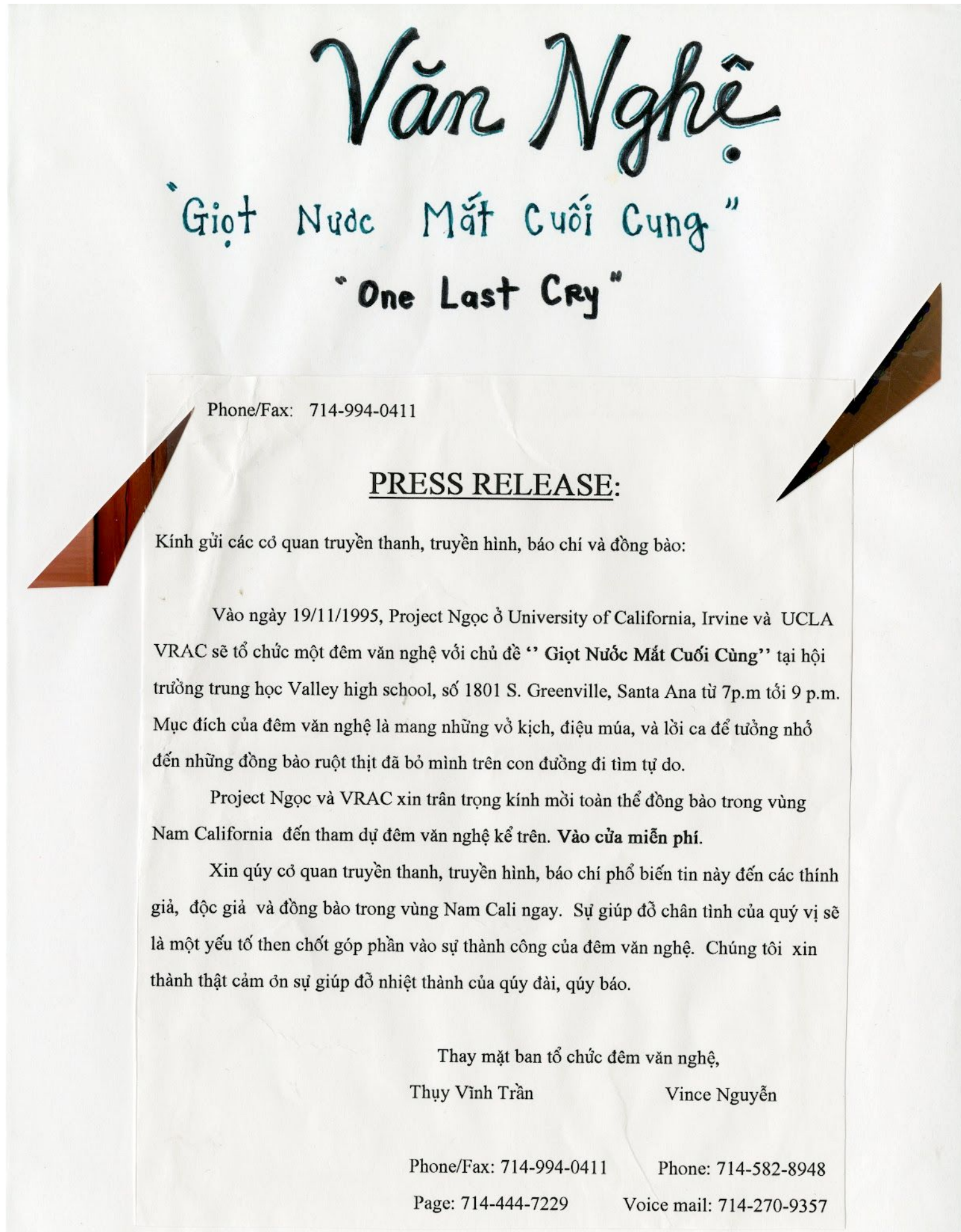

Figure 7. "One Last Cry" press release (1995)

Image Courtesy of UCI Libraries Special Collections, Southeast Asian Archive from the Project Ngọc Records, MS-SEA016_b04_f14. 
In a press release sent to Vietnamese news outlets, the students wrote that the purpose of this free event was to invite the Vietnamese community in Southern California to gather together in order to remember and mourn those who could not escape, had been lost at sea, or were still awaiting asylum (fig. 7). The students are not only remembering their parents, but also their parents' peers who were scattered across continents, including those still in Việt Nam or in refugee camps whether they be in Thailand, Hong Kong, Malaysia or the Philippines. The two-hour event included a moment of silence, musical performances, skits about their parents' journeys as boat people, and traditional Vietnamese dances using rice hats, scarves and umbrellas.

Interestingly, these images include handwritten inscriptions on cut strips of paper, suggesting that the photographs were previously placed in an album or a scrapbook as the versos of each photograph contain remnants of glue and paper. We can assume, then, that the inscriptions were placed beneath the photograph. To the creator or creators of the album, it was significant that they shared the titles of the song the groups were performing. Although not depicted, the presence of the audience is implied. In some cases, the inscriptions note how the audience received the performances. Such inscriptions will be discussed as they are crucial in contextualizing these photographs.

Furthermore, there are multiple re-readings and temporalities that exist and become activated or (re)produced within these photographs: the time the photograph was taken, the time the photograph was examined to be placed in an album, which invokes a recollection of the event and, again, how the event itself is meant to recall the first generation's memories of South Việt Nam and their journeys to freedom.

These 1.5 and second generation Vietnamese American youth, like their elders, are photographed in mid-performance, while singing on stage. This set of images is particularly 
significant not only due to youth involvement and organizing, just as importantly it illustrates methods of preserving South Vietnameseness and the responsibilities placed on the younger generation to maintain this sense of identity. ${ }^{84}$ The first three images in this analysis will consider the significance of youth participation in musical performances. The last four will examine the visual choreography and gendered roles in memory keeping in the Vietnamese diasporic community, particularly the labour of young women.

\section{Labour of the 1.5 and Second Generation}

The students begin the "One Last Cry" event with an initial welcome speech. Then, a large group of students from Project Ngọc and VRAC formally begin the program by singing Quốc Ca, the national anthem of South Việt Nam (fig. 8). They stand proudly on stage looking out in various directions into the audience. Here, women again wear colourful áo dài as they stand in the front row while their male peers stand behind them. Through this opening performance, the group of students immediately pay tribute to their parents' lost nation. Equally important, through this symbolic gesture they acknowledge and honour the hardships and sacrifices of the first generation.

${ }^{84}$ See again, Mimi Thi Nguyễn's The Gift of Freedom: War, Debt and Other Refugee Passages and erin Khuê Ninh Ingratitude:The Debt-bound Daughter in Asian American Literature both of which describes and critiques the circumstances in which refugees and children of refugees (in particular, daughters) must bear responsibilities and repay debt to either the state, their parents or to the community at large. 


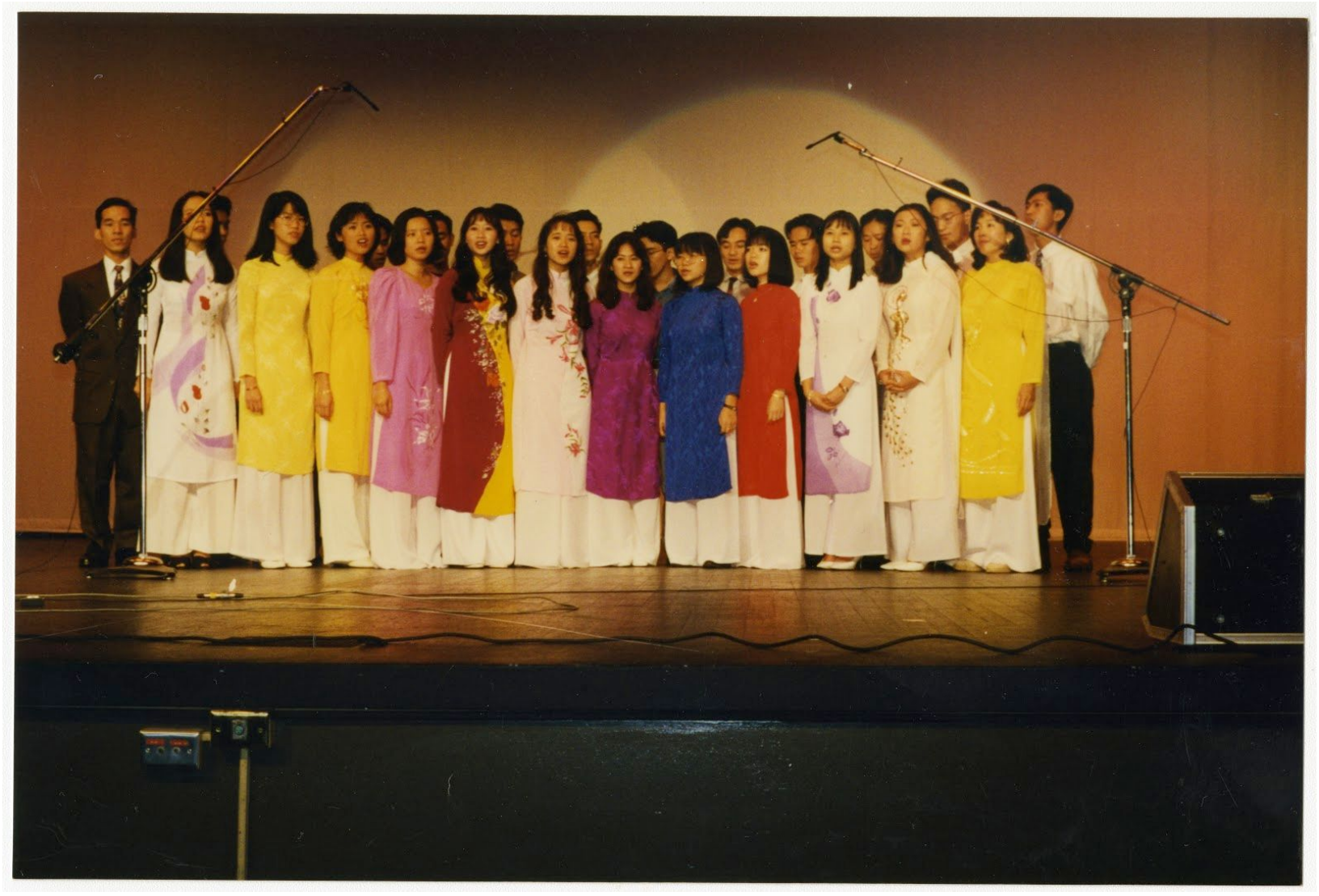

Figure 8. Students singing quốc ca (1995)

Image Courtesy of UCI Libraries Special Collections, Southeast Asian Archive from the Project Ngọc Records, MS-SEA016_b11_f02.

Following this welcome song of the national anthem, two students, Tony Ngô from UCLA and Quỳnh Trâm Vũ from Project Ngọc, perform the duet, "Xin Đời Một Nụ Cườr" (fig. 9). Ngô, in black dress pants and a white shirt sings into the microphone, while Trâm wears a black áo dài embellished with a rising dragon. She holds the microphone and glances down while she waits for her part in the duet. The ballad, which loosely translates to "Return Life A Smile," is about one's journey of leaving Saigon in search of freedom. The song was written by popular songwriter Nam Lộc in 1985, one week prior to the tenth anniversary of the Fall of Saigon. ${ }^{85}$ On YouTube there is a video of Lộc and Khánh Ly (a well-known singer who rose to fame during

\footnotetext{
${ }^{85}$ Nam Lộc, "Xin Doi Mot Nu Cuoi," Viet Bao Online, accessed April 28, 2019, https://vietbao.com/a211898/xin-doi-mot-nu-cuoi.
} 
the 1960s in South Việt Nam and who therefore is familiar to the diaspora) performing the duet with images of the war and refugees interweaving throughout the video. ${ }^{86}$ As Ngô and Trâm perform this duet 10 years after the ballad was written, they simultaneously address all generations, the first, 1.5 and other second generation youth. Ngô and Tram literally embody the roles of Lộc and Ly and therefore, take on the responsibilities to carry the memories and experiences of the first generation. The pair is successful in doing so as the inscription describes the performance as beautiful and moving as it "touched everyone's heart."

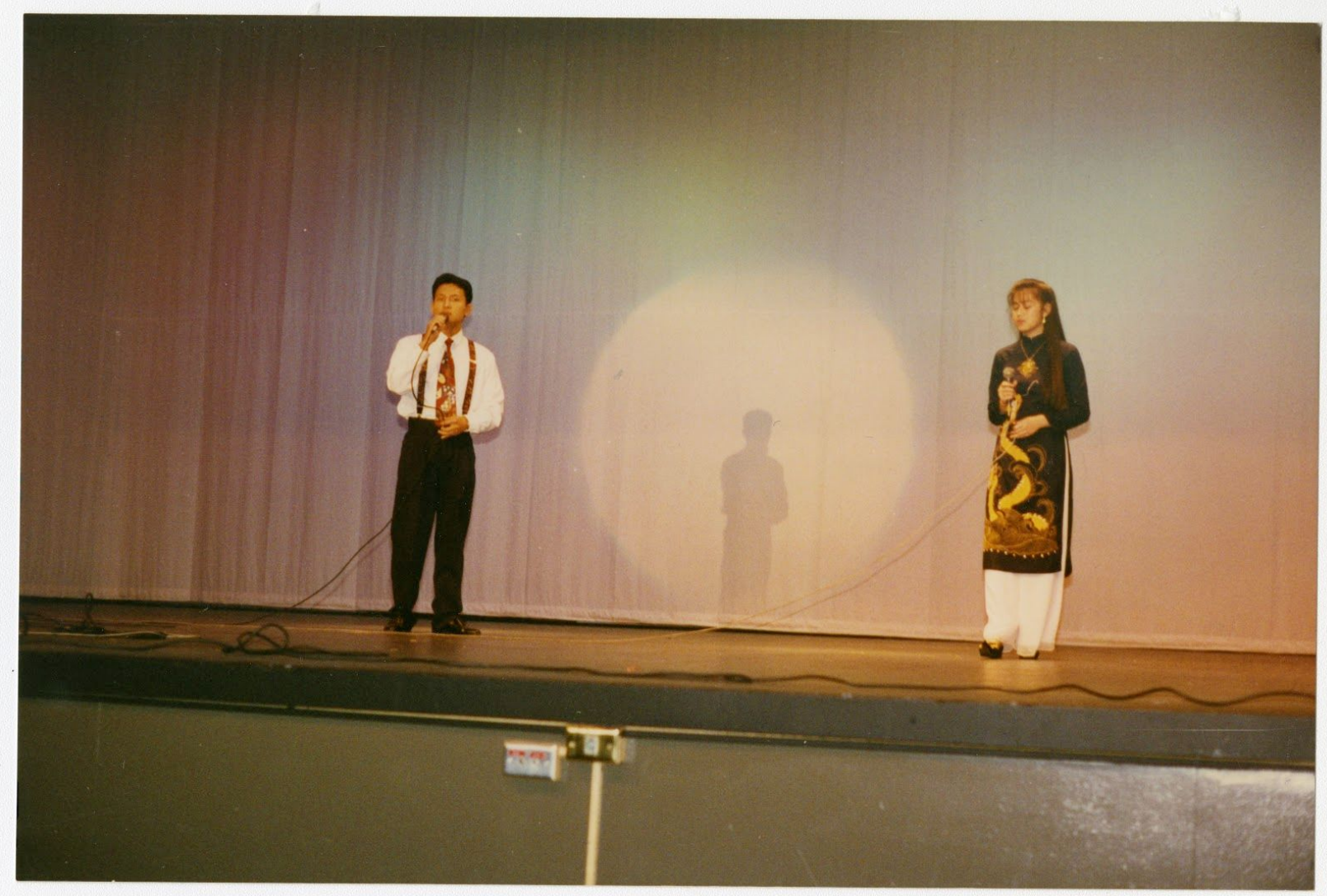

Figure 9. Tony Ngô and Quỳnh Trâm Vũ duet (1995)

Image Courtesy of UCI Libraries Special Collections, Southeast Asian Archive from the Project Ngọc Records, MS-SEA016_b11_f02.

\footnotetext{
86 "Khanh Ly Xin Doi Mot Nu Cuoi Video QuanNhacVang Com," YouTube video, accessed April 20, 2019, https://www.youtube.com/watch?v=hqZd3h2eTJE.

${ }^{87}$ See Figure 9a. in appendix.
} 


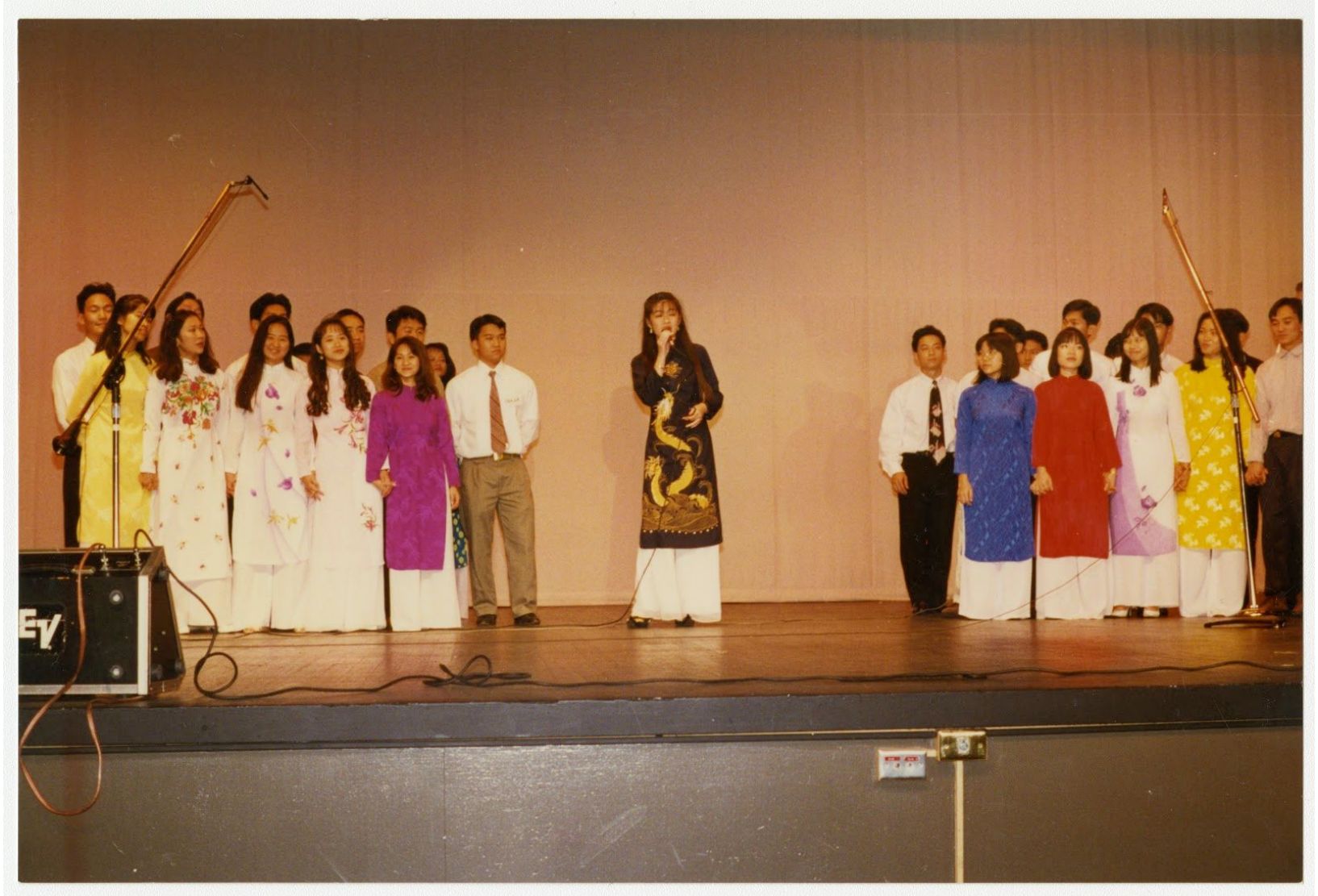

Figure 10. Project Ngọc and VRAC closing performance (1995)

Image Courtesy of UCI Libraries Special Collections, Southeast Asian Archive from the Project Ngọc Records, MS-SEA016_b11_f02.

The commemorative concert then closes with Trâm again on stage, performing in the center between two groups of men and women who hold hands as a gesture of solidarity (fig. 9). Two inscriptions are also included for this photograph. The first caption states that Tram "started the audience up with her elegant voice," while the second inscription reads, "In closing our meaningful Văn Nghệ, VRAC and Project Ngọc got together one last time to lead the audience in the theme song, "Bên Em Đang Có Ta" (fig. 10a). The song, written in 1991, became Project Ngọc's closing theme song at their events. The ballad, about remembering others in the shared journey and experience of becoming refugees, was a fitting theme song for the organization, whose mandate was to raise awareness of refugee issues and struggles. 
Though one might quickly glance over such photographs or even disregard them as just another community event, nevertheless they are important to our understanding of the invisible and visible desires of the community. It is critical to note that, unlike the first generation's văn nghê, the music performed at this event were songs that were produced in the South Vietnamese diaspora. This included music that accompanied the skit and dances as discussed later in this section. For the 1.5 and second generation born in America who did not have to undergo a journey of escape, singing these songs allows them to imagine otherwise and embody their parents' experiences.

The student-organized văn nghệ echoes the symbolic teachings of the first generation's to remember quê hương always. While such events are meant to gather the community to remember and not forget their homeland, for this youth-organized event there is another layered purpose: to honour the first generation's journeys of escape and their hardships. While the two events are nearly 15 years apart, the youth of Project Ngọc and VRAC employ the same strategic memory projects and they produce similarly composed photographs. Not only did youth participate in spectatorship by attending such commemorative events, but these images, either these literal ones or others alike of first generation performances, must also have been reproduced and circulated.

In The Public Image, authors Robert Hariman and John Lucaites, as outlined above, define spectatorship as a social relationship and civic capability in which spectatorship of photography can then provide a way of existing in the world with others. ${ }^{88}$ Hariman and Lucaites suggest that we should consider photography as a dimension of abundance in which images and like images become circulated and seen repeatedly. This is done through a "civic contract"

\footnotetext{
${ }^{88}$ Robert Hariman and John Lucaites, The Public Image: Photography and Civic Spectatorship (University of Chicago Press, 2017), 6.
} 
created by each image that exists, understanding that, because the image will be read again by others, it virtually connects all parties as "virtual citizens."

These vernacular images of community events and performances of the Vietnamese diaspora are abundant. It illuminates the community's desires and urgency to remember through commemorative events and through photographs of these events. For the second generation, viewing the performances at the time of the event or viewing the photographs afterwards, helps connect them virtually to both the first, 1.5 and second generations. ${ }^{90}$ Knowing that others are seeing and will see the same type of images, creates a sense of imagined community and fosters a connection to others across the South Vietnamese diaspora.

${ }^{89}$ Hariman and Lucaites, The Public Image, 69-70.

90 The viewing of photographs creates a virtual kinship through a sense of an imagined community or imagined meeting places. See Benedict Anderson's Imagined Communities and Joan M. Schwartz and James R. Ryan's Picturing Place: Photography and the Geographical Imagination for more on the relationship between photography creating imagined meeting places through the production and circulation of images. 


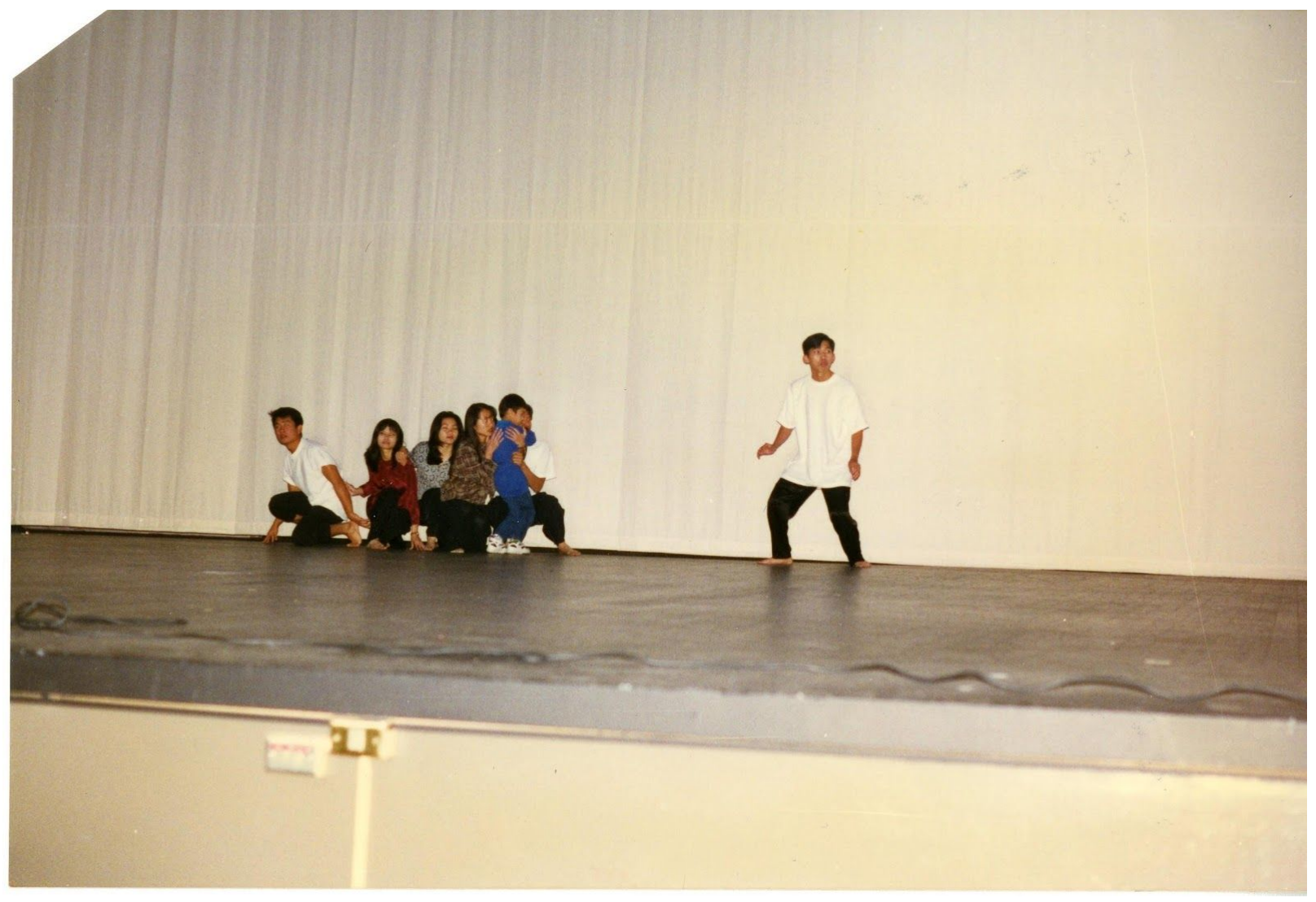

Figure 11. "Shadow of the Sea" skit (1995)

Image Courtesy of UCI Libraries Special Collections, Southeast Asian Archive from the Project Ngọc Records, MS-SEA016_b11_f02.

This virtual connection or kinship amongst the diaspora becomes apparent again in the "Shadow of the Sea," a wordless skit, "which captures the tragic experience of the boat people" and is described as "a heartfelt performance done by Project Ngọc." ${ }^{91}$ On the bare stage a group of five students huddle and crouch together with frightened and unsure expressions. Two of the students presumably act as a mother and father, and hold onto a young boy dressed in blue. To the right of the group, a student identified as Long stands slightly above and looks out, as though to make sure the group can cross safely to the next step of their journey. As the skit

${ }^{91}$ See Figure 11a. in appendix. 
recalls the journey of the boat people, the students dutifully pay respect to the first generation coming to America.

Through the use of music and skits performed, "One Last Cry" illustrates the 1.5 and second generation's debt to their parents for their sacrifices. As their parents received the gift of freedom, this makes them "indebted to empire"- meaning they are indebted to the United States for granting their freedom and acceptance as refugees. ${ }^{92}$ Their children in turn, are indebted to the first generation and to those that died at sea in search of a better life. As a result, the younger generation must navigate multiple and layered postmemories. First, they must balance their own parents' recollection of South Việt Nam with the community's memory of South Việt Nam. Then, they must also negotiate their parents and the collective diaspora's memories of their journeys of escape. This difficult navigation is but one of the burdens and complex filial obligations imposed onto the younger generation of the diaspora. They inherit memories and debt that is not their own and yet, to be good Vietnamese children they must continue carrying these responsibilities.

\section{Vietnamese American Women: Performing the Virtues and Values of the Diaspora}

In addition to these burdens, there are gendered expectations involved with these performances. As vernacular images are abundant, this allows us to see recycled tropes employed by the Vietnamese diasporic community as a means to negotiate selective acts of remembering. In this last section, I analyze the dances and skits performed by the students

\footnotetext{
${ }^{92}$ Mimi Thi. Nguyễn, The Gift of Freedom: War, Debt, and Other Refugee Passages (Durham and London: Duke University Press, 2012).

See also: Anh Ngo's working paper, "“Cộng Đồng (Community)" presented at States of Refuge Workshop at McMaster University, Hamilton, Canada, May 10, 2018. Ngo's paper expands on Nguyen's concept of "the gift of freedom" and the inheriting generation, being the younger generation, while they are the beneficiary of their parents' hardships, they must also "repay this refugee generation for their sacrifices by means of academic and economic achievements."

See also: Espiritu, Body Counts, 142. On Vietnamese children having to come to terms with the loss and the costs placed onto their parents.
} 
throughout the "One Last Cry" event as well as a student skit on pageantry where such gendered choreography is explicit as young Vietnamese American women are tasked with representing a nation (fig.11,12,13,14). Here, I consider the implications of this gendered division of labour.

When we reconsider figure 11 of the skit of the boat people, it becomes apparent that only the young women wear traditional Vietnamese clothing, specifically grey, red and brown patterned áo bà ba while the male performers wear contemporary white t-shirts and black pants. The áo bà ba differs from the fitted áo dài as it consists of a loose, scooped-neck shirt that goes slightly below the torso paired with black silk pants. ${ }^{93}$ The casual everyday outfit, typically worn by women in rural Southern Việt Nam, is usually made out of airy fabric, allowing for comfortable movement for farm work. The display of the áo bà ba is both a tribute to the first generation of rural background and evokes a remembrance of quê hương and therefore, of South Việt Nam.

The áo bà ba and more notably, the áo dài have great visual and symbolic significance throughout the event. A photograph of eight female students in áo dài form a circle on stage facing each other with rice paper hats placed on the ground (fig. 12). Each girl holds a light white scarf around their necks. The photograph is cut in a dynamic manner and with it, the inscription reads, " "the angels of my life," complimented by the audience...male of course". ${ }^{94}$ The caption is telling, as whoever wrote it was acutely aware that the women were likely to be complimented and appreciated without question, by men. If this dance is similar to the ones I have seen before with these props, the girls would then meet in the center of the circle and draw

\footnotetext{
93 "Áo bà ba," Wikipedia, accessed April 28, 2019, https://en.wikipedia.org/wiki/\%C3\%810_b\%C3\%A0_ba.

${ }^{94}$ See Figure 12a. in appendix.
} 
out one hand. ${ }^{95}$ As they do so, the white scarves will float and follow their movements, enhancing their "angelic" manner.

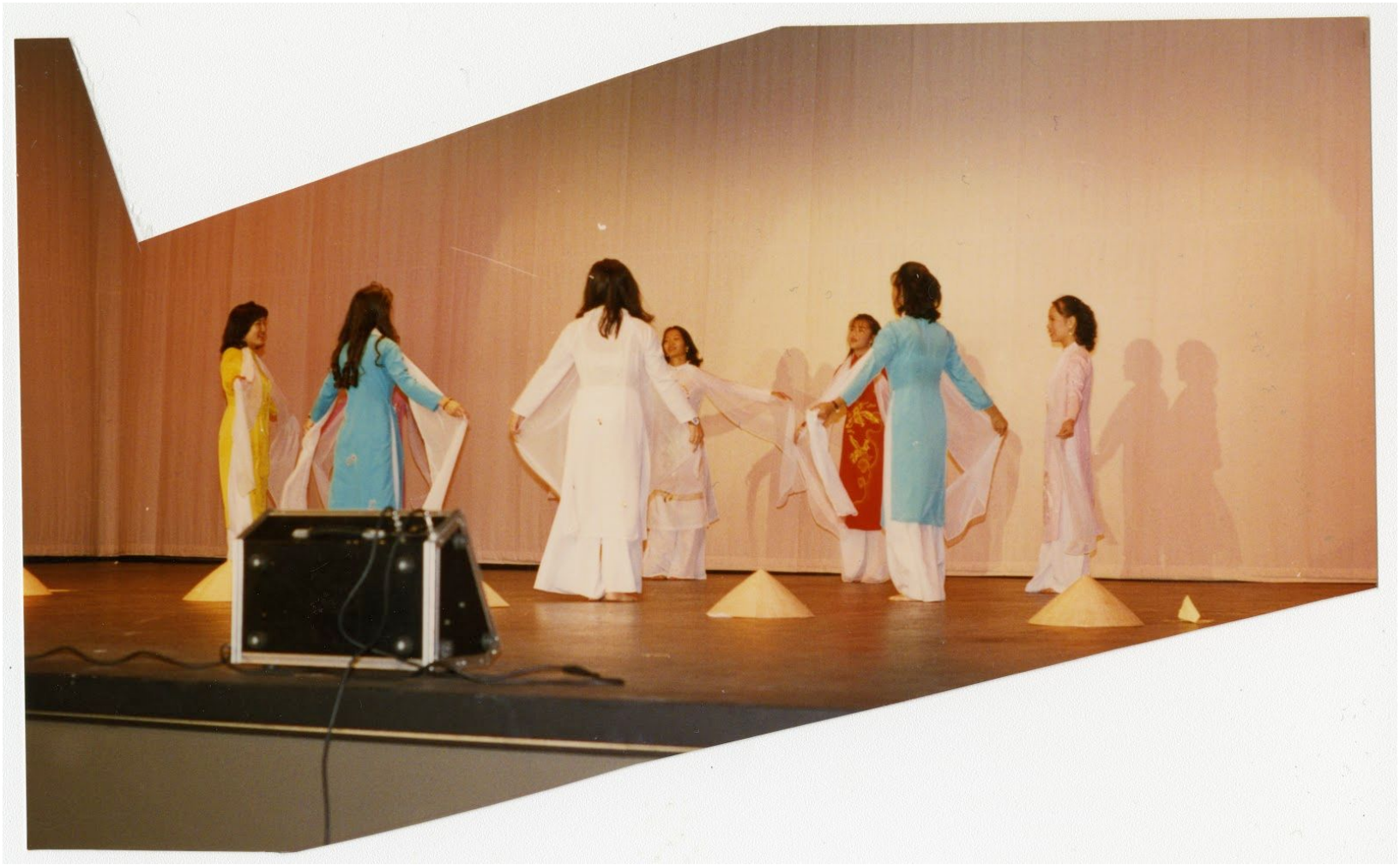

Figure 12. Dance performance with scarves in a circle (1995)

Image Courtesy of UCI Libraries Special Collections, Southeast Asian Archive from the Project Ngọc Records, MS-SEA016_b11_f02.

The familiarity of the students with this dancing is intriguing. Where did they learn this choreography and how to perform on stage? As Nguyễn and Cunningham note, "audiovisual images become so important for young Vietnamese as a point of reference, as a tool for validation and as a vehicle towards self-identity." ${ }^{, 96}$ Likely, the students learned the choreography and storytelling through ASIA Entertainment Inc. and "Paris by Night" musical productions. Both of these organizations are music studios that operated within the Vietnamese diaspora, and were founded by the first generation. Considering that these photographs are

\footnotetext{
95 I've participated in a Vietnamese Student Association cultural show while at Ryerson University where we did this exact formation with white scarves as well.

${ }^{96}$ Nguyễn and Cunningham, "The Popular Media of the Vietnamese Diaspora," 135.
} 
from 1995, we can assume that this group had been exposed to recordings of these extravagant performances that the companies were known for producing.

In fact, the founders of Thuý Nga, the studio that produces "Paris By Night," saw the need for music and cultural production for overseas Vietnamese. Tô Văn Lai and his wife, Thuý Nga opened "their music-operation business, which had also operated in Saigon under the same name since 1968." ${ }^{\prime 97}$ Paris By Night was then re-founded in 1983, producing live performances, music videos and CD's of nhạc trước '75 and contemporary music. The first 10,000 videotaped copies were released in America in 1989 and quickly gained popularity. ${ }^{98}$ Due to their immediate success in the late 80's and early 90's, Thuý Nga business operations would become bi-continental with the founding office in Paris, France and an additional office started in Orange County, California and overseen by their daughter. The rising popularity of this diasporic media industry, as evident in the opening of a second office in Orange County, makes it plausible that Paris By Night and its rival, Asian Entertainment Inc. influenced the student performances.

Again, recall that Project $\mathrm{Ngọc}$ was a student organization at $\mathrm{UCl}$, in close proximity to Little Saigon, the center of diasporic Vietnamese produced media where such images and audiovisual images were being circulating and reproduced. ${ }^{99}$ With the reproduction of images of events and performances for example, through Vietnamese daily newspapers or copycat recorded performances, ideologies of the community and visual tropes become reproduced and recycled. Additionally, it is likely that, due to the popularity of these media, youth may have encountered them in both public and private spaces such as local restaurants or at home.

\footnotetext{
${ }^{97}$ Quyen Do, "'Paris by Night' sells big // VIDEO: The unique series propels a Westminster businessman to the forefront of Vietnamese pop culture," The Orange County Register, December 29, 1995.

${ }^{98}$ Ibid.

${ }^{99}$ Lieu, "Private Desires on Public Display," 9.
} 
Therefore, it is unsurprising to see traces and influences of the Vietnamese diasporic media in these student performances as the students try to make sense of their diasporic identity.

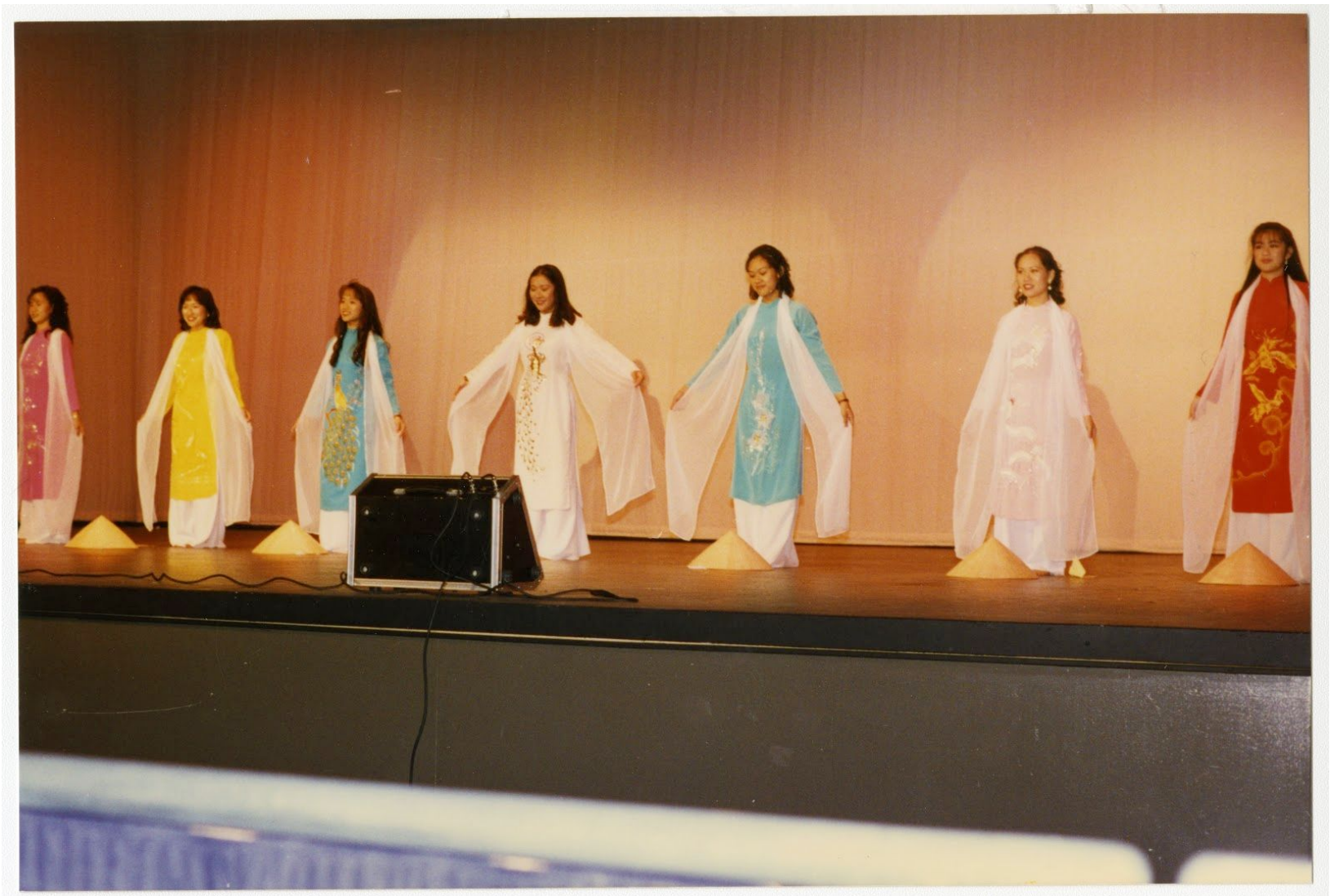

Figure 13. Dance performance with scarves (1995)

Image Courtesy of UCI Libraries Special Collections, Southeast Asian Archive from the Project Ngọc Records, MS-SEA016_b11_f02.

Notably, the girls coordinate their choreography to songs that evoke nostalgia either through the lyrics or through the use of traditional Vietnamese string instruments. In the first dance with the scarves, the girls dance to the song "Một Thoáng Quê Hương." verse:

Đẹp biết bao... quê hương cho ta chiếc áo nhiệm màu Dù ở đâu... Pa-ris, Luân Đôn hay ở những miền xa Thoáng thấy áo dài... bay trên đường phố

100 "Một Thoáng Quê Hương," YouTube video, accessed May 10, 2019, https://www.youtube.com/watch?v=YKV2gVZtVYA.

In the umbrella dance, they perform to the song "Duyên Quê." 
Sẽ thấy tâm hồn... quê hương ở đó... em ơi...!

How beautiful ... my homeland gives me No matter where ... Pa-ris, London or in far places

Quick glimpse of the áo dài... flying on the street

Will see the soul ... the homeland is there ... dear ...!

The lyrics indicate that no matter where in the Vietnamese diaspora, it is through the áo dài that both the spectator and person wearing it, will remain connected to quê hương.

The áo dài, a long-sleeved, high-collared dress that hugs the body with slits down its sides, is paired with high waisted, flowing silk pants that peek through. If one walks in a particular manner while in an áo dài, the front slit will flutter while the back slit of the dress will glide and float behind. The girls in the dance accentuate this fluttering, breezy quality through their use of scarves as seen more clearly in figure 13. As they glide to the front of the stage, they delicately hold the scarves, spreading the fabric out like wings.

As evident in the examples drawn from the Paul Tran Files and the Project Ngọc Records, traditional Vietnamese clothing appears repeatedly in photographs and is worn exclusively by women in the first, 1.5 , and second generation. Natalie Huynh Chau Nguyen in Memory is Another Country: Women of the Vietnamse Diaspora, notes that traditionally, women are "perceived to be the keepers and transmitter of culture... they are custodians of the suppressed and silenced histories of the Vietnamese diasporas." ${ }^{101}$ The áo dài as a dress still worn today, it symbolizes purity, Vietnamese femininity, and serves as a method of romanticizing a pre-1975 Vietnam. The prominent displays of the dress throughout the event "invokes nostalgia and timelessness associated with a gendered image of the homeland." ${ }^{102}$ The dress outlines the curves of a woman's body while seemingly remaining conservative and

\footnotetext{
${ }^{101}$ Natalie Huynh Chau Nguyen, Memory is Another Country: Women of the Vietnamese Diaspora (Praeger, 2009), 163.

102 Lieu, The American Dream in Vietnamese, 61.
} 
elegant. Though the dress was once worn frequently by schoolgirls and women of upper and middle class, when the communist regime took over, the áo dài was linked to the "old regime" and it was no longer worn in public. ${ }^{103}$

For Vietnamese women of the first generation to wear áo dài in the diaspora is an act to reclaim the national dress and return to the past. This display, however, simultaneously articulates gendered ideas of nationhood as the lost nation is also referred to as Mẹ Việt Nam, Mother Việt Nam. Often, refugee and immigrant identity asserts cultural superiority and claims visibility in highly gendered ways. ${ }^{104}$ These claims are especially applied to young women. As Espiritu and other feminist scholars have noted, cultural anxiety concerning sexuality and the dichotomy of good girl-bad-girl is "most apparent with regard to adolescent girls." ${ }^{105}$ This dichotomy allows families and the broader community to "discipline their daughters as racial/national subjects as well as gendered ones... [to become] guardians of "authentic" cultural memory." 106

Through dance performances and by wearing traditional clothing in the course of these performances, women are expected to display a "timelessness" of the community's lost nation. For young Vietnamese American women of the 1.5 and second generation, the áo dài takes on new forms. It becomes a tool to be considered "good" and authentically Vietnamese. Through its display, both the wearers of the garment and its spectors, are able to access their culture and heritage. It also allows the women to participate in conjuring memories of quê hương. As the dress invokes a "past that is pure, innocent and untainted by war," women of the second generation are perceived to be 'untainted' by direct memories of the war and are therefore, pure

\footnotetext{
${ }^{103}$ Lieu, The American Dream in Vietnamese, 62.

104 Yến Lê Espiritu, Home Bound: Filipino Lives Across Cultures, Communities, and Countries (Berkeley: University of California Press, 2003): 157-158.

${ }^{105}$ Espiritu, Home Bound, 173.

106 Ibid.
} 
and innocent themselves. ${ }^{107}$ As they don áo dài, their bodies take on new layers of symbolism. Their bodies present the past through nostalgia of pre-1975 South Việt Nam as well as the future, by preserving the virtues of Vietnamese femininity and identity for later generations. The display of áo dài becomes an important strategic memory project of the Vietnamese diasporic community that shape these young women, who are tasked with the responsibility of carrying the community's values and visual identity forward.

While the younger generation is responsible for negotiating postmemories and Vietnameseness, it is specifically young women that must prove, compete and constantly display their Vietnameseness at community events. This is done through the public spectacle of pageantry, where second generation women must also navigate between Vietnamese and American cultural values while displaying a commitment to their community and culture as seen in the last image of my case study.

${ }^{107}$ Lieu, The American Dream in Vietnamese, 61. 


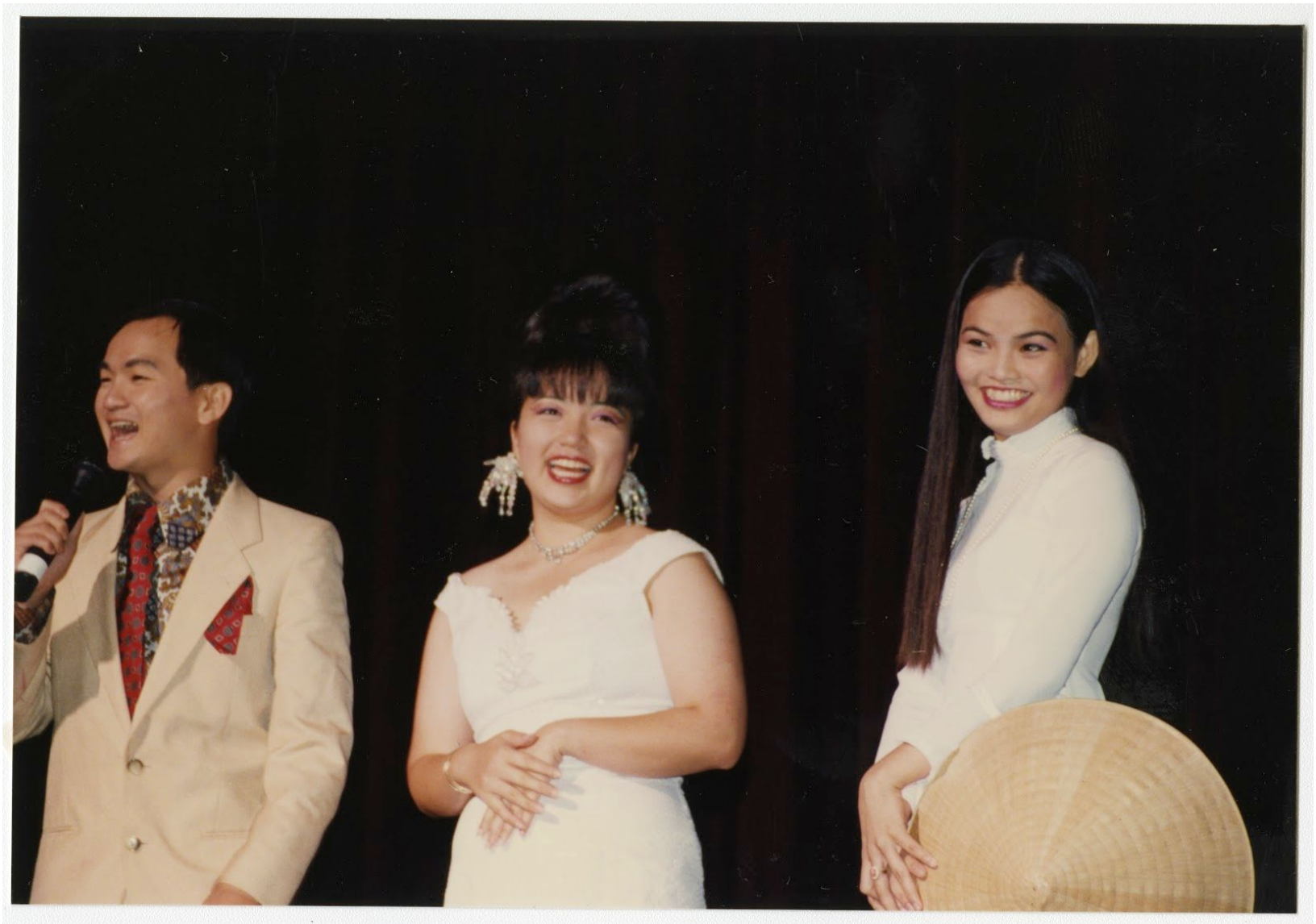

Figure 14. Miss Áo bà ba Contest (c.1990)

Image Courtesy of UCI Libraries Special Collections, Southeast Asian Archive from the Project Ngọc Records, MS-SEA016_b11_f02.

Though this photograph is not part of the "One Last Cry" event by Project Ngọc, nevertheless, I include this photograph in my analysis because it explicitly illustrates the burden of gendered performance and expectations and the 1.5 and second generation's acknowledgement of such (fig.14). Depicted in this image is a spoof on pageantry as suggested by the inscription of "Miss Áo bà ba Contest" since typically, the áo bà ba is worn everyday and does not signify glamour for a pageant title. ${ }^{108}$ To the left, a man wears a beige suit and speaks into the microphone, perhaps while telling a joke to the audience as his co-master of ceremonies stands beside him in mid laugh. She wears a contemporary white dress (from the

${ }^{108}$ See Figure 14a. in appendix. 
1990s) with her hair up in a top bun. Beside her, a girl in a white áo dài with straight black hair smiles at the audience while shyly holding a rice hat. Perhaps then, this girl is acting as a contestant.

Through this skit, the women in the photograph illustrate and perform multiple values of Vietnamese womanhood expected of them as Vietnamese Americans. It is possible in this performance, "contestants" were required to present themselves wearing áo dài and áo bà ba, such displays were often a judging criteria in pageants. Although this image does not depict a real pageant, it still illustrates how young Vietnamese women are culturally disciplined.

As Lieu contends, since the late 1970's, pageants have been permanently integrated in Vietnamese American celebrations and events. ${ }^{109}$ For pageants, young Vietnamese American women constantly have to perform and engage in these activities to preserve Vietnamese culture by visually displaying their commitment through clothing along with the traits and virtues associated with it. Wearing áo dài can demonstrate one's ability to be elegant, graceful, and timeless. In contrast, the áo bà ba symbolizes the idea of everyday beauty and hard work as it invokes memories of the countryside and rural labour. The public spectacle of pageants suggests that for young women in the diaspora, to be Vietnamese one must be elegant and fashionable through the áo dài and yet also be humble and not superficial through the áo bà ba.

In Espiritu's analysis of gendered morality, as in women's dedication to their families

and thus their community, womanhood becomes

idealized as the repository of tradition, the norms that regulate women's behaviours become a means of determining and defining group status and boundaries. As a consequence, the burdens and complexities of cultural representation fall most heavily on immigrant women and their daughters.

\footnotetext{
109 Lieu, "Private Desires on Public Display," 136.

${ }^{110}$ Espiritu, Home Bound: Filipino Lives Across Cultures, Communities, and Countries, 160.

Note: the term behaviour has been adapted to Canadian spelling.
} 
This includes the importance of visual cultural representation through sartorial display as women and young girls are subjected to wearing traditional clothing.

Men on the other hand, may wear suits or casual clothing at remembrance events. Moreover, the very act of men standing behind women on stage symbolizes the weight of the constant public performances women are expected to demonstrate. This includes performing for the Vietnamese community as well as to outside groups in how they perceive the Vietnamese. Therefore, as men step back on stage, it illustrates that they do not have the same obligations of visually representing a nation.

Through these specific community performances, men display their Vietnameseness differently. They do so by participating and upholding gender expectations and patriarchal values in the diaspora that invokes the cultural practices of pre-1975 South Việt Nam. For instance, men of the first generation who were once part of the elite can reclaim and lessen the effects of this defeat--which entailed a loss of status and privileges-through compelling others

to maintain Vietnamese cultural values and traditions for future generations. ${ }^{111}$ As evident throughout all the photographs discussed in this paper, women and young girls bear the burden of visibly displaying their Vietnameseness and are tasked with upholding the values and teachings of the older generation to the community and to the greater public.

\section{Conclusion}

I began this thesis because I wanted to understand why I was seeing similar photographs of familiar events of remembrance across the diaspora. Why do these images instill in me a longing for a lost nation to which I have no direct connection?

\footnotetext{
${ }^{111}$ Nguyen, "Without the Luxury of Historical Amnesia," 138.
} 
Vernacular photographs are often regarded as banal or unimportant. Similarly, the narratives and experiences of the Vietnamese people during the Việt Nam war and its aftermath are often rendered as invisible despite their hypervisibility being documented by the media as a spectacle. By attending to the visual registers of vernacular photographs made by the Vietnamese diasporic community, we are able to see how they navigate the aftermaths of war. Unfolded in the vernacular are their (in)visible desires for community building and their methods of preserving a South Vietnamese identity. The photographs of early remembrance gatherings from the ' 80 s demonstrates the political urgency of the community to gather and create collective identity within the context of losing their nation of South Việt Nam.

Resettling in Orange County following the end of the Việt Nam war, this post-war generation gathered and established community spaces for them to hold onto their South Vietnamese heritage and identity. Emerging from trauma, the first generation's memories and longings for quê hương were transmitted to their children via postmemory. Public events like musical performances and pageants were physical spaces where such memories were shared and transmitted. The photographs of these events through their multi-temporal quality also serve as spaces for mediating memory and post-memory among the first, 1.5 and second generations. Moreover, the seriality of the photographs inherent to the vernacular genre, illustrate the repetition of visual tropes employed by the community. This includes the display of the heritage flag or traditional clothing used to successfully anchor the community's selective collective memory over time and space.

Furthermore, though an analysis of repetitive visual tropes, the hidden teachings of the first generation and consequently the teachings of the photographs also unfold. They inform the younger generation about preserving a South Vietnamese identity as well as honouring and remembering the community's quê hương and sacrifices. Just as importantly, these images 
provide a critical lens on the gendered public display of Vietnameseness where the burden of performance and memory keeping is placed onto young Vietnamese American women.

As younger future generations become further removed from having any immediate connection to Việt Nam, the responsibility of authenticity may prompt them to question who is more Vietnamese than whom, possibly creating an unspoken competition between themselves. This too, will lead to the continued preservation and dominance of a South Vietnamese identity in the diaspora. As youth will turn to these types of vernacular images and other cultural productions to shape their own visual understandings of their parents' histories and memories, they will consequently become culturally disciplined from them. Thus, while this desire to remember not just the homeland but also a particular vision of this homeland persists, the Vietnamese diasporic community will hold onto and cherish the visual tropes that have sustained their nostalgic imaginings for more than forty years. 


\section{Appendix}

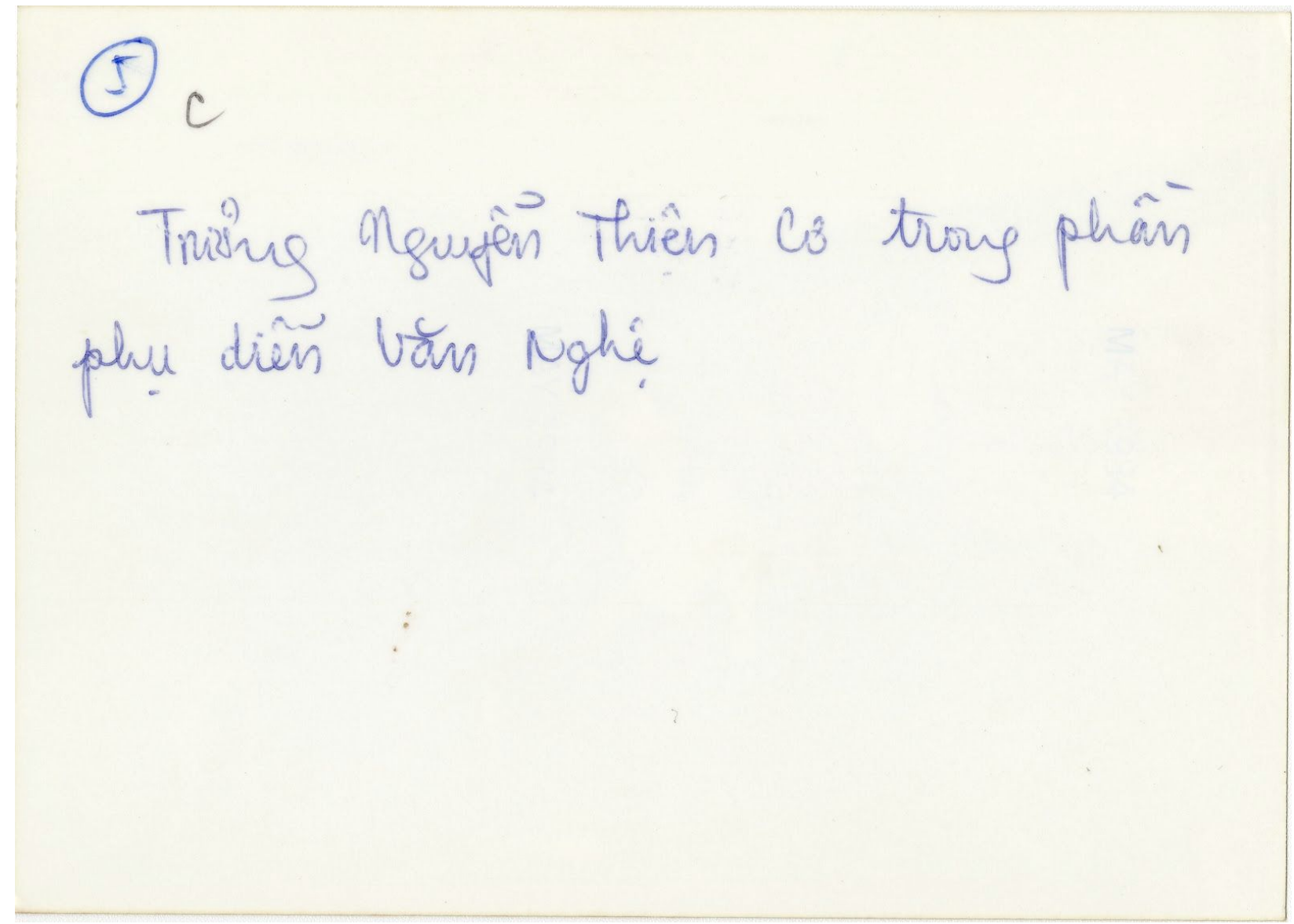

Figure 1a. Verso of Trường Nguyễn strumming a guitar (c.1980)

Image Courtesy of UCI Libraries Special Collections, Southeast Asian Archive from the Paul Tran Files, MS-SEA002_b04_f19. 


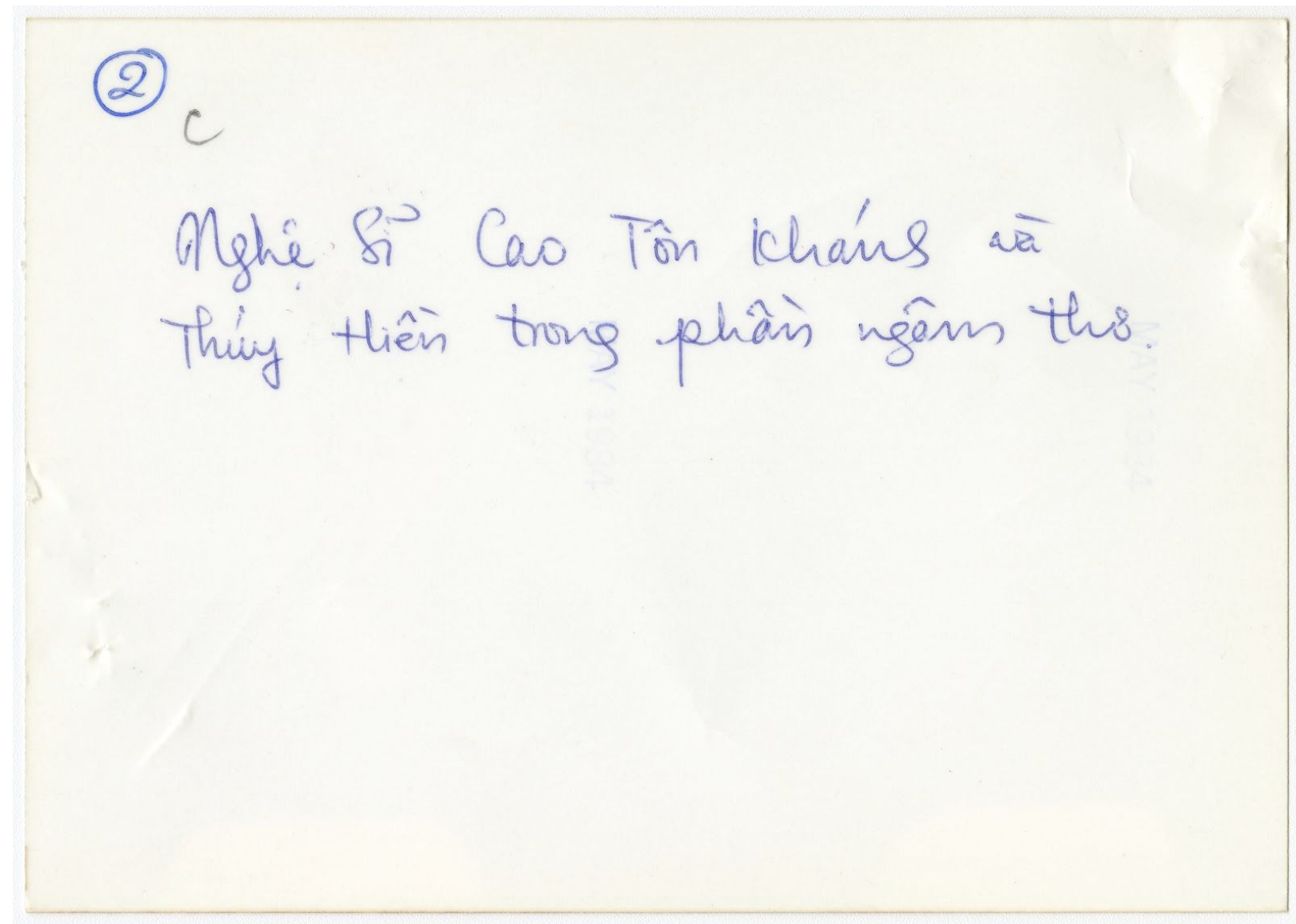

Figure 2a. Verso of Cao Tôn Kháng and Thúy Hiền performance (c.1980)

Image Courtesy of UCI Libraries Special Collections, Southeast Asian Archive from the Paul Tran Files, MS-SEA002_b04_f23. 


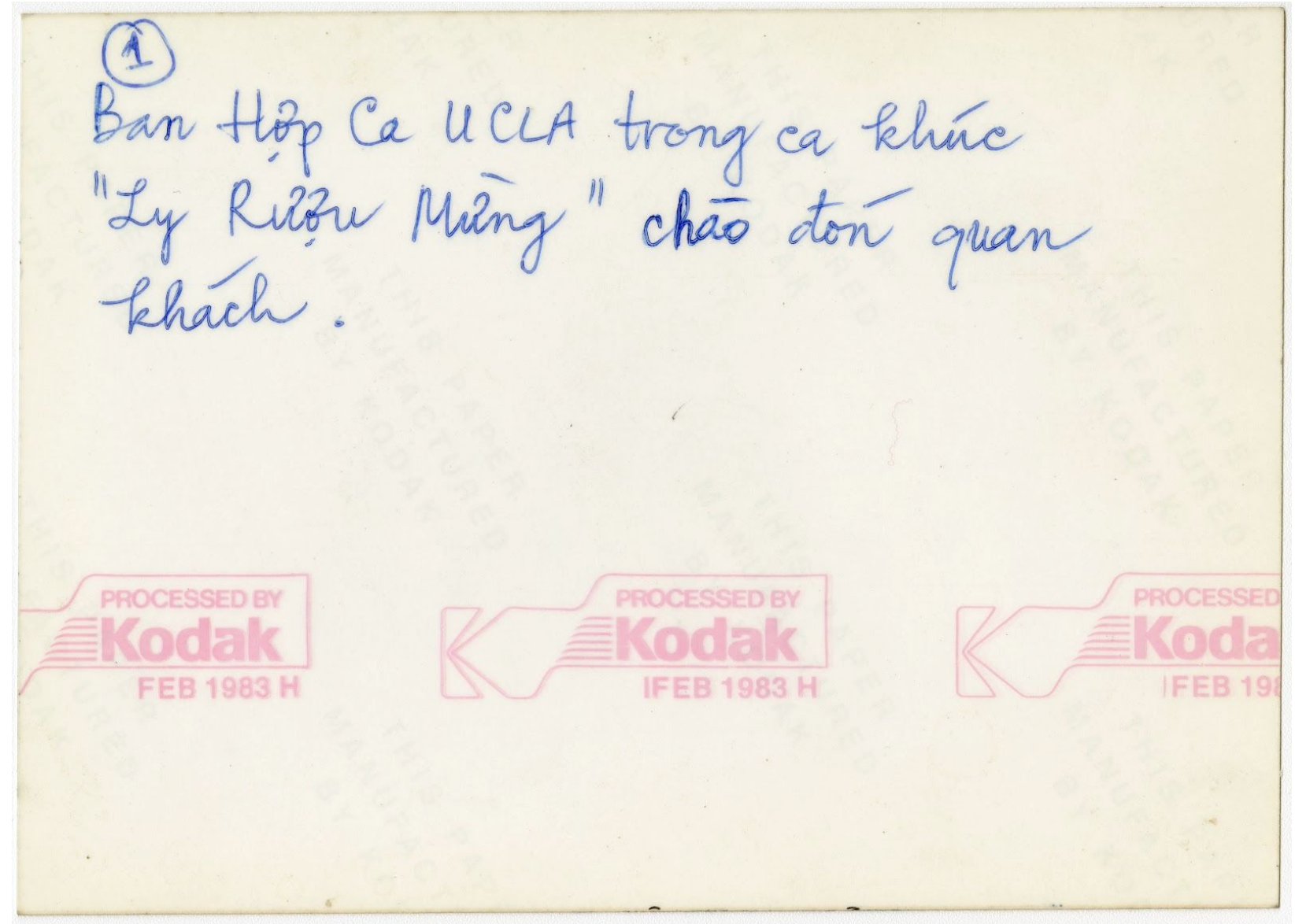

Figure 3a. Verso of UCLA choir performance of "Ly Rượu Mùng" (c.1980)

Image Courtesy of UCI Libraries Special Collections, Southeast Asian Archive from the Paul Tran Files, MS-SEA002_b04_f23. 


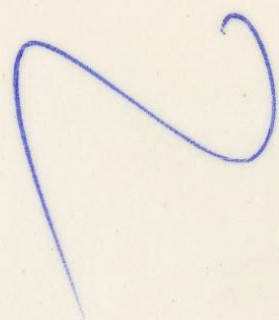

Figure 4a. Verso of Choir performance (c.1980)

Image Courtesy of UCI Libraries Special Collections, Southeast Asian Archive from the Paul Tran Files, MS-SEA002_b04_f23. 


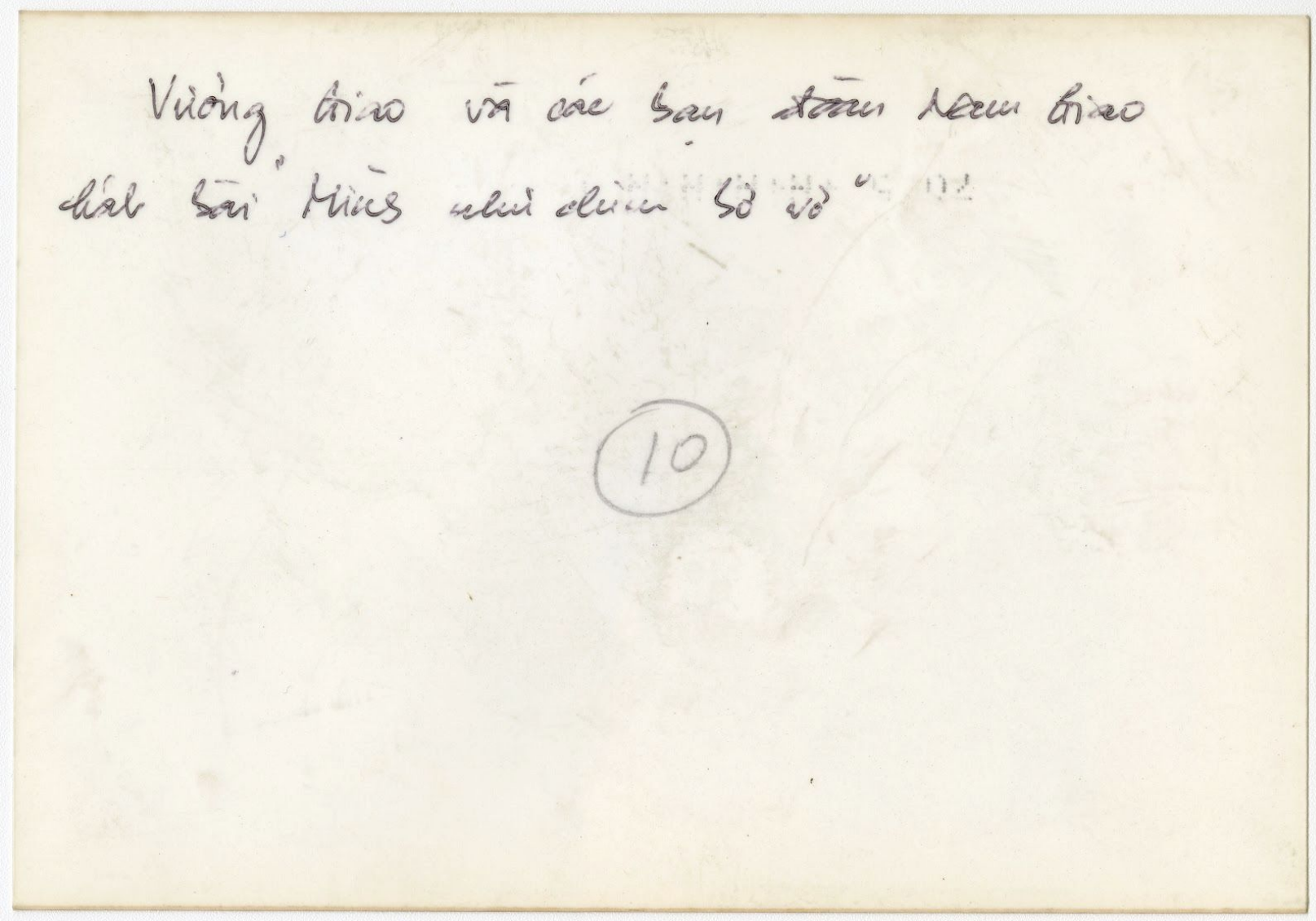

Figure 5a. Verso of Vưong Giao and youth performance (c.1980)

Image Courtesy of UCI Libraries Special Collections, Southeast Asian Archive from the Paul Tran Files, MS-SEA002_b04_f23. 


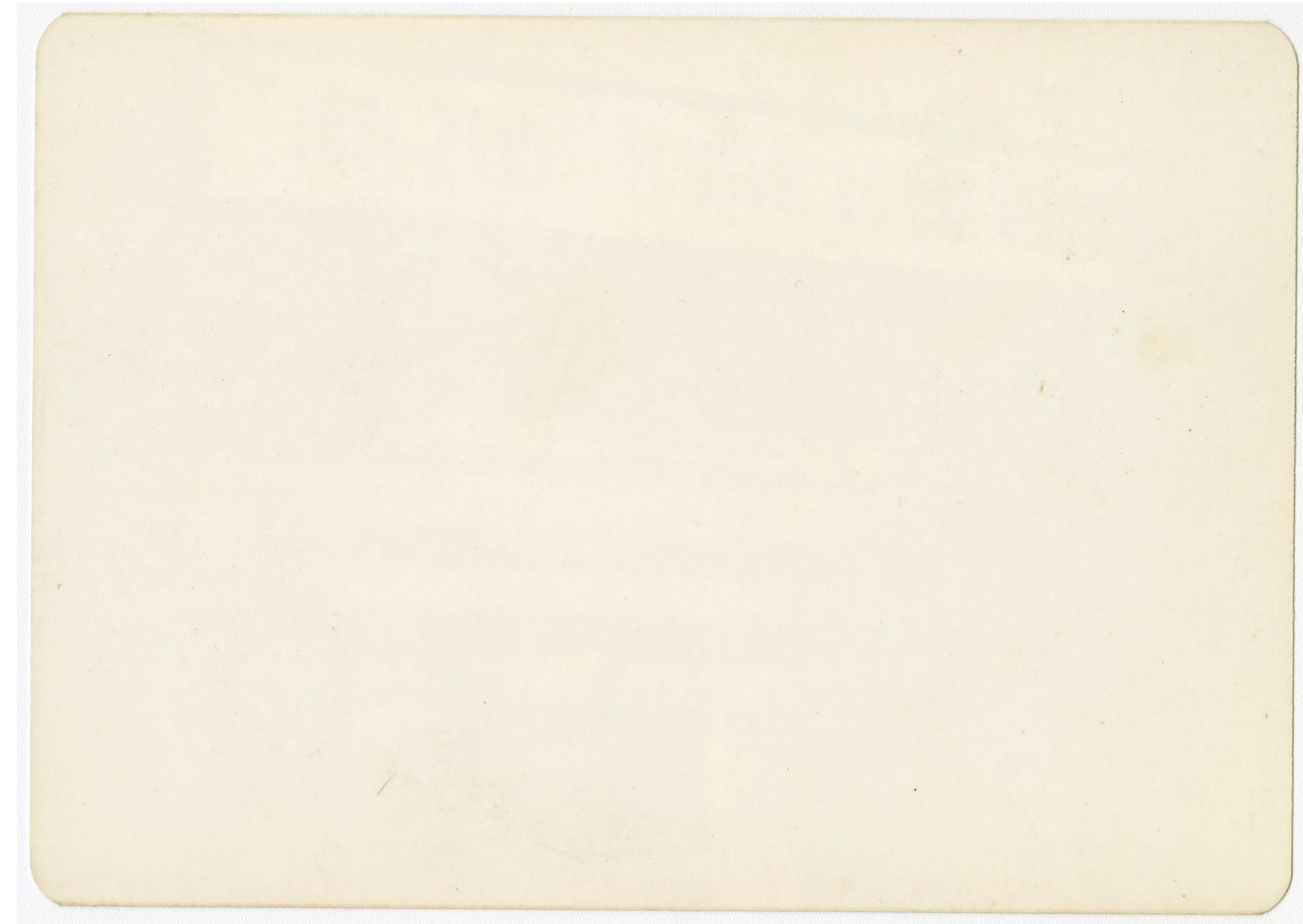

Figure 6a. Verso of Youth commemorating April 30th (1981)

Image Courtesy of UCI Libraries Special Collections, Southeast Asian Archive from the Paul Tran Files, MS-SEA002_b04_f23. 


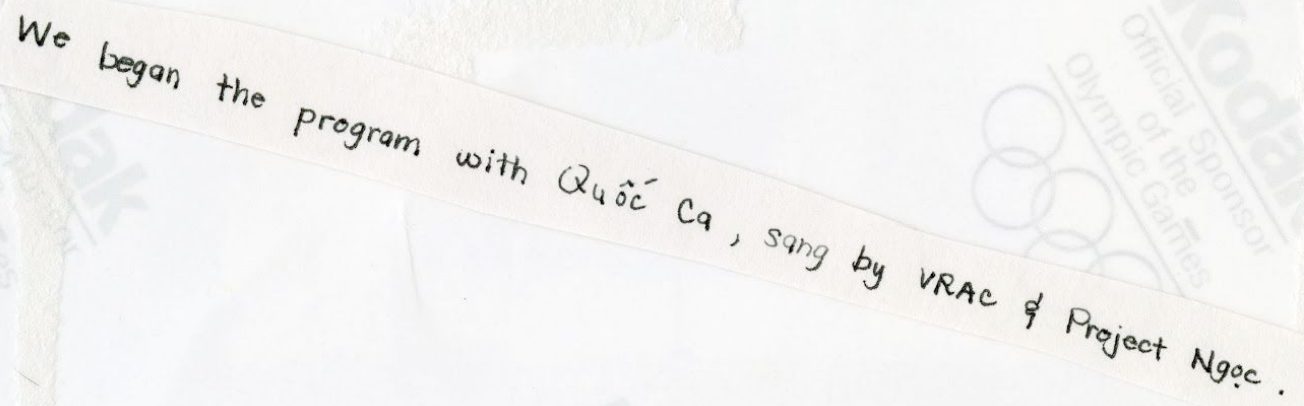

Figure 8a. Verso of Students singing quốc ca (1995)

Image Courtesy of UCI Libraries Special Collections, Southeast Asian Archive from the Project Ngọc Records, MS-SEA016_b11_f02. 


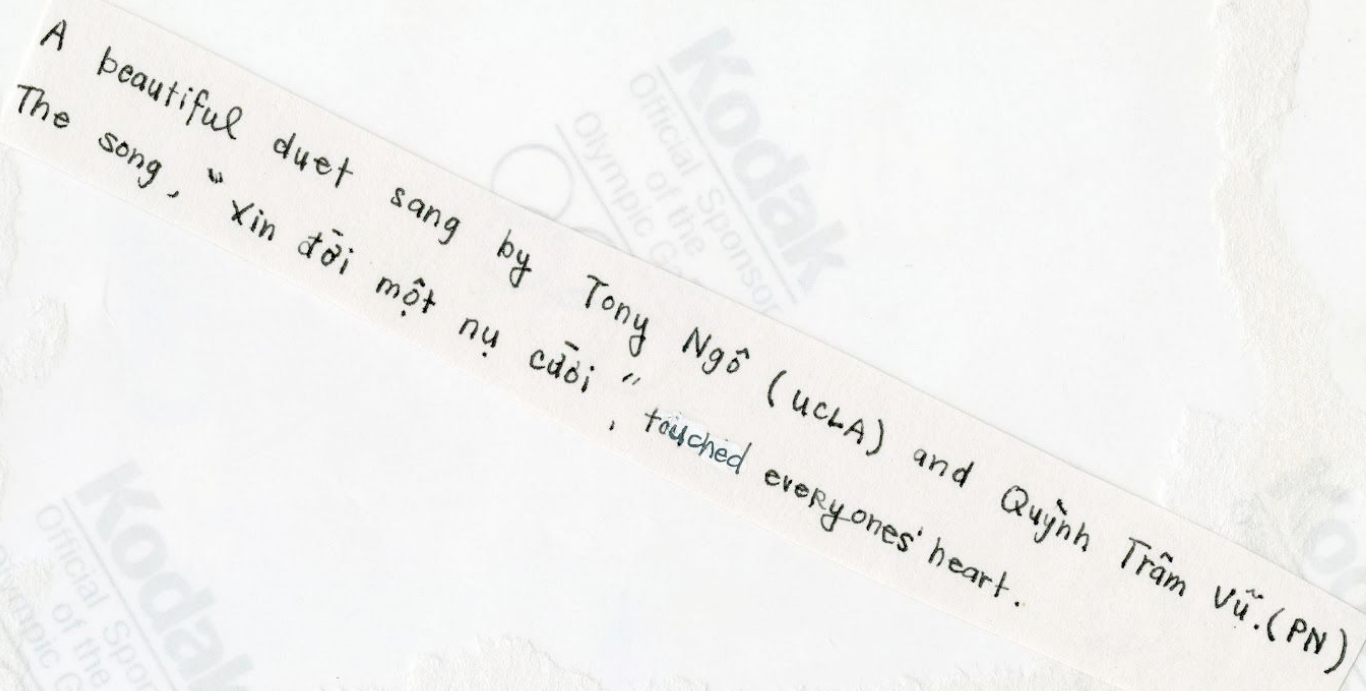

Figure 9a. Verso of Tony Ngô and Quỳnh Trâm Vũ duet (1995)

Image Courtesy of UCI Libraries Special Collections, Southeast Asian Archive from the Project Ngọc Records, MS-SEA016_b11_f02. 


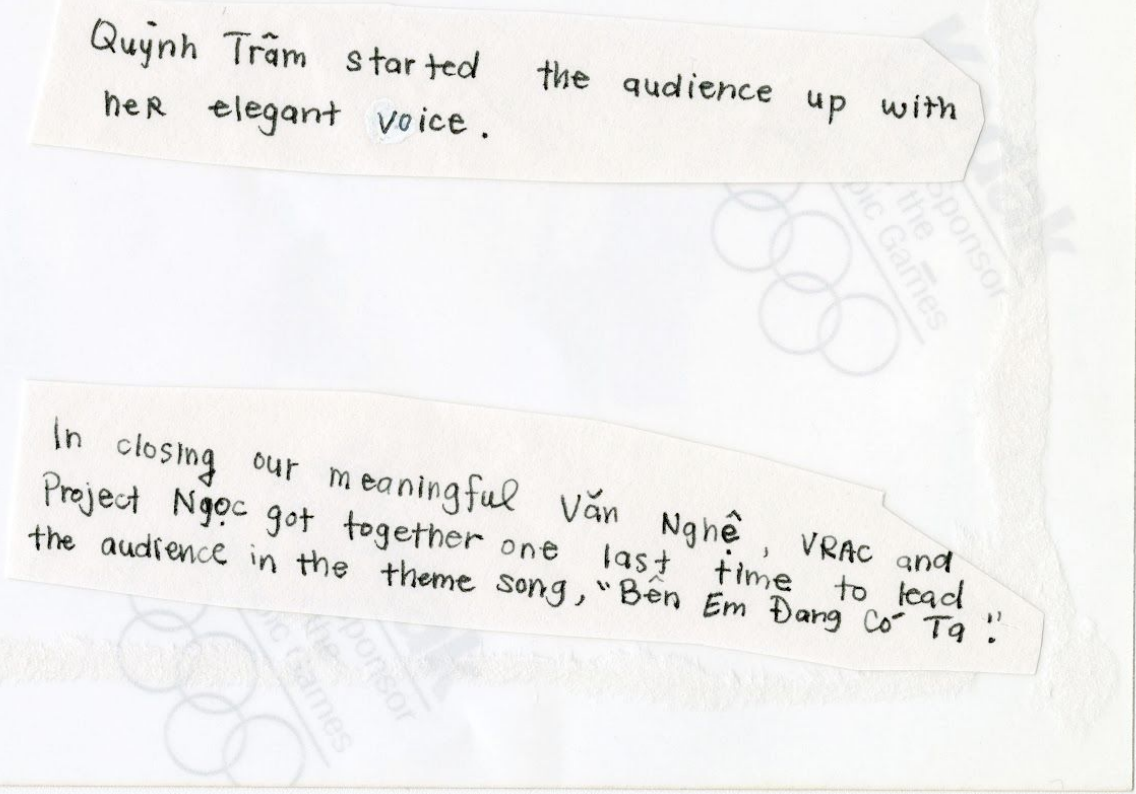

Figure 10a. Verso of Project Ngọc and VRAC closing performance (1995)

Image Courtesy of UCI Libraries Special Collections, Southeast Asian Archive from the Project Ngọc Records, MS-SEA016_b11_f02. 


$$
\begin{aligned}
& \text { Vü, Shadow of the Sea', captures } \\
& \text { the tragic experience of the boat } \\
& \text { people. } \\
& \text { A heart felt performance dore by } \\
& \text { Project Ngoc. }
\end{aligned}
$$

Figure 11a. Verso of "Shadow of the Sea" skit (1995)

Image Courtesy of UCI Libraries Special Collections, Southeast Asian Archive from the Project Ngọc Records, MS-SEA016_b11_f02. 


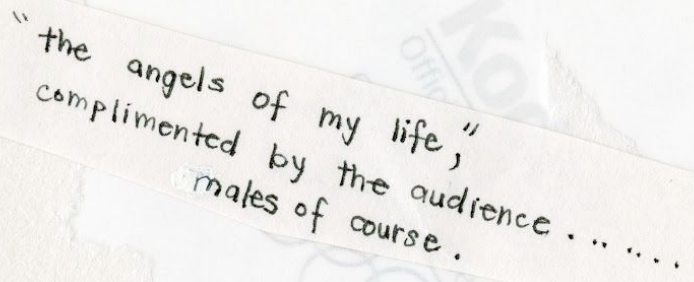

Figure 12a. Verso of Dance performance with scarves in a circle (1995)

Image Courtesy of UCI Libraries Special Collections, Southeast Asian Archive from the Project Ngọc Records, MS-SEA016_b11_f02. 


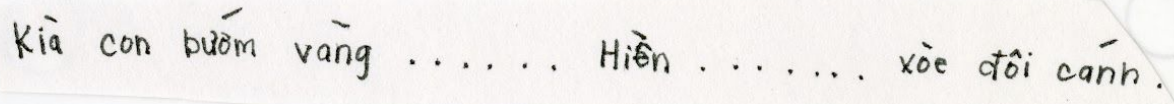

Figure 13a. Verso of Dance performance with scarves (1995)

Image Courtesy of UCI Libraries Special Collections, Southeast Asian Archive from the Project Ngọc

Records, MS-SEA016_b11_f02. 


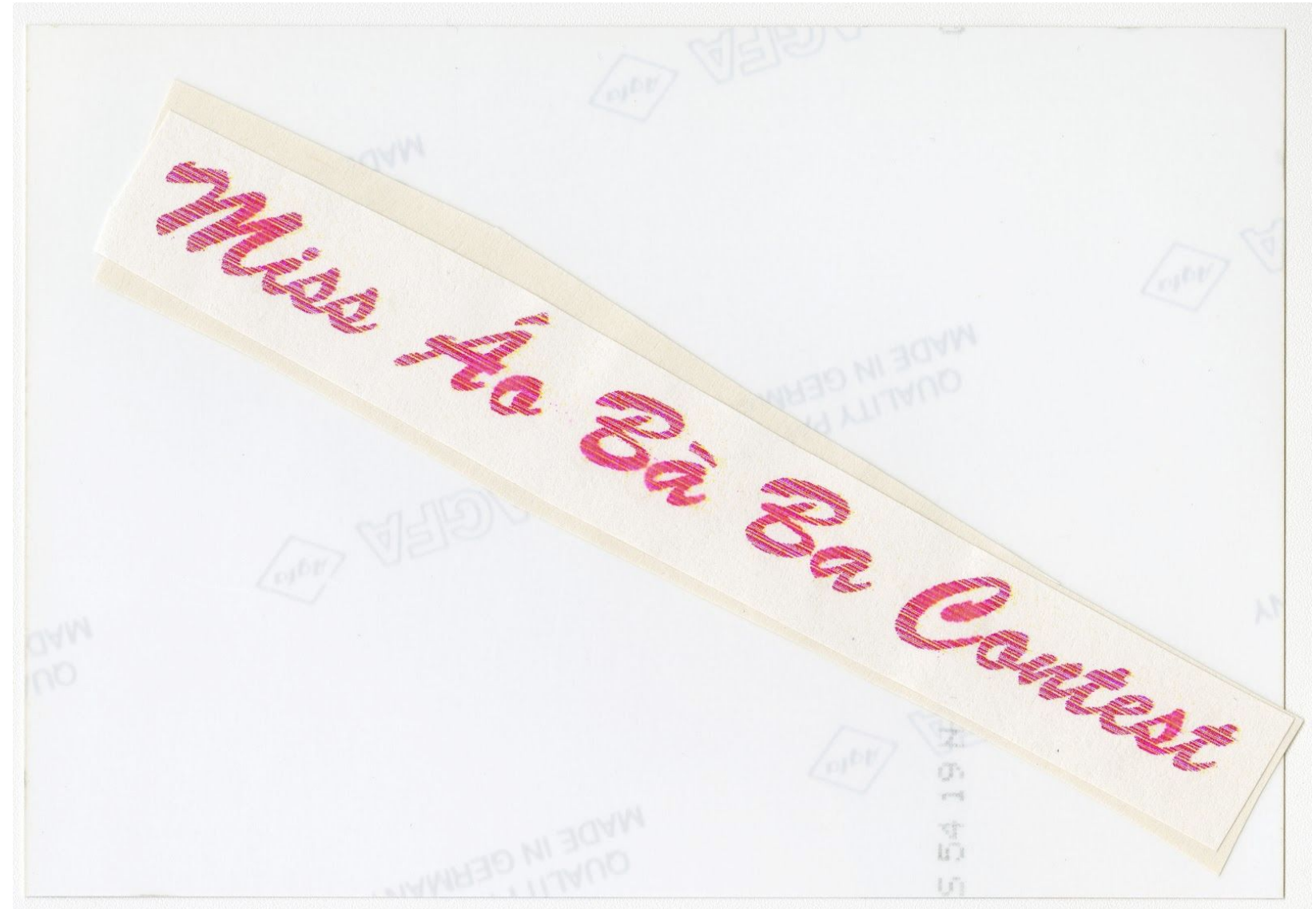

Figure 14a. Verso of Miss Áo bà ba Contest (c.1990)

Image Courtesy of UCI Libraries Special Collections, Southeast Asian Archive from the Project Ngọc Records, MS-SEA016_b11_f02. 


\section{Bibliography}

Aguilar-San Juan, Karin. Little Saigons. Minneapolis: University of Minnesota Press, 2009.

Batchen, Geoffrey. "Vernacular Photography." Oxford Art Online, January 22, 2014. https://doi.org/10.1093/gao/9781884446054.article.T2254188.

Bui, Long T. Returns of War: South Vietnam and the Price of Refugee Memory. New York University Press, 2018.

Campt, Tina M. Image Matters: Archive, Photography, and the African Diaspora in Europe. Duke University Press, 2012.

Campt, Tina M. Listening to Images. Durham and London: Duke University Press, 2017.

Chương, Phạm Đình. Ly Rượu Mừng (1952), https://www.youtube.com/watch?v=CF2R2yJ--V8.

Do, Quyen. “'Paris by Night' sells big // VIDEO: The unique series propels a Westminster businessman to the forefront of Vietnamese pop culture." The Orange County Register. December 29, 1995.

Edwards, Elizabeth. "Objects of Affect: Photography Beyond the Image." Annual Review of Anthropology 41, no. 41 (October 21, 2012): 221-34.

Espiritu, Evyn Lê. "Who Was Colonel Ho Ngoc Can? Queer and Feminist Practices for Exhibiting South Vietnamese History on the Internet." Amerasia Journal 43, no.2 (2017): 3-24.

Espiritu, Yến Lê. Home Bound: Filipino Lives Across Cultures, Communities, and Countries. Berkeley: University of California Press, 2003.

Espiritu, Yến Lê. Body Counts: The Vietnam war and Militarized Refuge(es). University of California Press, 2014.

Hariman, Robert and John Lucaites. The Public Image: Photography and Civic Spectatorship. University of Chicago Press, 2017.

Hirsch, Marianne and Leo Spitzer. "We Would Not Have Come Without You: Generations of Nostalgia." American Imago 59, no. 3 (2002): 253-76.

Hirsch, Marianne. The Generation of Postmemory: Writing and Visual Culture After the Holocaust. New York: Columbia University Press, 2012.

Huang, Josie. "Infographic: 40 percent of nation's Vietnamese immigrants call California home." Multi-American. Accessed May 10, 2019.

https://www.scpr.org/blogs/multiamerican/2014/08/25/17200/california-vietnamese-immig rant-orange-county/. 
Huynh Chau Nguyen, Natalie. Memory is Another Country: Women of the Vietnamese Diaspora. Praeger, 2009.

Le Cao Thanh Hai. "Crafting a New Self in the Diaspora: A Study of the 1.5 Generation of Vietnamese Americans." PhD diss., University of Kansas, 2013.

Lieu, Nhi T. "Private Desires on Public Display: Vietnamese American Identities in Multi-Mediated Leisure and Niche Entertainment." PhD diss., University of Michigan, 2004.

Lieu, Nhi T. The American Dream in Vietnamese. University of Minnesota Press, 2011.

Linh Valverde, Caroline Kiều. "Making Transational Viet Nam: Vietnamese American Community — Viet Nam Linkages through Money, Music and Modems." PhD diss., University of California Berkeley, 2002.

Lộc, Nam. "Xin Doi Mot Nu Cuoi." Viet Bao Online. Accessed April 28, 2019. https://vietbao.com/a211898/xin-doi-mot-nu-cuoi.

Nguyễn, Mimi Thi. The Gift of Freedom: War, Debt, and Other Refugee Passages. Durham and London: Duke University Press, 2012.

Nguyen, Kim. "Without the Luxury of Historical Amnesia": The Model Postwar Immigrant Remembering the Vietnam War Through Anti Communist Protests. "Journal of Communication Inquiry 34, no. 2 (2010): 134-50.

Nguyễn, Tina and Stuart Cunningham. "The Popular Media of the Vietnamese Diaspora." Media International Australia, Incorporating Culture \& Policy no. 91 (1999): 125-47.

Nguyễn, Việt Thanh. Nothing Ever Dies: Vietnam and the Memory of War. Harvard University Press, 2016.

Ngô, Anh. "Cộng Đồng (Community)." Paper presented at States of Refuge Workshop at McMaster University, Hamilton, ON, Canada. May 10, 2018.

Phu, Thy. "Diasporic Vietnamese Family Photographs, Orphan Images, and the Art of Recollection." Trans Asia Photography Review 5, no.1 (Fall 2014): http://hdl.handle.net/2027/spo.7977573.0005.102.

Project Ngọc and VRAC-UCLA. Giọt Nước Mắt Cuối Cùng Chương trình (One Last Cry program pamphlet). 1995.

Special Collections and Archives, The UC Irvine Libraries, Irvine, California. "Guide to Project Ngoc Records, MS-SEA016." Accessed, March 19, 2019.

https://oac.cdlib.org/findaid/ark:/13030/kt8z09p8pd/. 
Special Collections and Archives, The UC Irvine Libraries, Irvine, California. "Paul Tran files on Southeast Asian refugees. MS-SEA002." Accessed March 11, 2019. https://oac.cdlib.org/findaid/ark:/13030/tf8f59p1tg/dsc/\#dsc-1.8.7.

Statistics Canada 2017 Profile. "2016 Census." Statistics Canada Catalogue no. 98-316-X2016001. Accessed June 23, 2019. http://www12.statcan.gc.ca/census-recensement/2016/dp-pd/prof/index.cfm?Lang=E.

Sturken, Marita. Tangled Memories : Berkeley: University of California Press, 1997.

Tran, Jacinda. "From Deadbeat Dad to Great Benefactors: Picturing Rescue by (Re)Scripting U.S. Masculinity through the 1988 Amerasian Homecoming Act." Invisible Vietnam: Counter-archives and the Visual Mediation of War. Paper presented at the Society for Cinema and Media Studies Conference, Toronto, ON, Canada. March 18, 2018.

University of California Irvine Libraries. "Southeast Asian American Studies: Studying the Vietnamese, Cambodian, and Laotian Diaspora." Accessed March 20, 2019. https://guides.lib.uci.edu/southeastasianamerican.

Vietnamese Student Union Bruins. "History." Accessed May 1, 2019. http://www.vsubruins.com/about/history/.

Võ Đăng, Thuy, Linda Trinh Võ, and Trâm Lê. Vietnamese in Orange County. Charleston, South Carolina: Arcadia Publishing, 2015.

Wikipedia. "Áo bà ba.” Accessed April 28, 2019. https://en.wikipedia.org/wiki/\%C3\%81o_b\%C3\%A0_ba.

Wikipedia. "A glass of wine." Accessed April 15, 2019. https://translate.google.com/translate?hl=en\&sl=vi\&u=https://vi.wikipedia.org/wiki/Ly_r\% 25C6\%25B0\%25E1\%25BB\%25A3u_m\%25E1\%25BB\%25ABng\&prev=search.

YouTube comment. long vuong viet. "this song to be sing every Lunar New Year of South Viet Nam not north viet nam." January 2019.

https://www.youtube.com/watch?v=-zGQ2qVsCwQ.

YouTube video. "Khanh Ly Xin Doi Mot Nu Cuoi Video QuanNhacVang Com." Accessed April 20, 2019, https://www.youtube.com/watch?v=hqZd3h2eTJE.

YouTube video. "Một Thoáng Quê Hương." Accessed May 10, 2019, https://www.youtube.com/watch?v=YKV2gVZtVYA. 